\title{
MANAJEMEN SDM GLOBAL
}

\author{
Onsardi $^{1}$ Ratna Juita ${ }^{2}$ \\ ${ }^{1,2}$. Dosen tetap Fakultas Ekonomi dan Bisnis \\ Universitas Muhammadiyah Bengkulu \\ onsardi@umb.ac.id
}

\begin{abstract}
Changes in the business paradigm require changes in the management of company activities. One dimension of company activities that requires a new approach to management is human resource management. The old view of human resource management must be abandoned and replaced with a new view. The old view sees human resources not in a vital position, whereas the new view sees human resources as a vital aspect in a company that is as human capital or an asset for a company.
\end{abstract}

Keywords: Human Resource Management, Company Performance

\section{BAB I \\ PERAN MANAJEMEN SUMBER DAYA MANUSIA \\ DAN KINERJA PERUSAHAAN}

\section{Latar Belakang}

Pengaruh dari berubahnya kondisi bisnis, berubahnya struktur organisasional dan berubahnya kepemimpinan telah memaksa departemen sumber daya manusia untuk memperluas perspektif mereka atas peran dan fungsi mereka hanya dalam waktu yang sangat singkat. Ketika perusahaan bergerak dari hanya mementingkan obsesinya lalu menjadi fokus pada konsumen, misi dan peran organisasi, maka mereka telah dipaksa untuk membuat perubahan atas struktur organisasional mereka. Secara tradisional, sebuah departemen sumber daya manusia diorganisasikan sebagai departemen staf yang melayani jalur operasi. Perubahan dalam ekspetasi kepemimpinan memandatkan sebuah peran baru bagi profesional sumber daya manusia, dan apabila para profesional sumber 
daya manusia tidak berubah, maka mereka akan menggenggam banyak bom kritik (Johnston. J, 1996).

Berbagai pengaruh perubahan yang terjadi menuntut organisasi untuk membuka diri terhadap tuntutan perubahan dan berupaya menyusun strategi dan kebijakan yang selaras dengan perubahan lingkungan bisnis (Wayne, 1991; Schuller and Jackson, 1996 dalam Ignatius R.S, 2002) yang akan bergantung pada kemampuan organisasi dalam menyesuaikan diri terhadap perbahan lingkungan. Artinya suatu organisasi harus mampu menyusun strategi dan kebijakan yang ampuh untuk mengatasi setiap perubahan yang terjadi.

Keberhasilan penyusunan kebijakan dan strategi organisasi akan didukung lebih banyak oleh fungsi manajerial yang ada (Datton \& Jackson, 1987 dalam Ignatius R.S, 2002) dan salah satu bidang fungsional strategi yang menjadi perhatian adalah manajemen sumber daya manusia.

Seperti dikutip oleh Veronica (1999) bahwa sebuah pendekatan strategis terhadap manajemen sumber daya manusia harus mencakup pembuatan dan pelaksanaan satu rangkaian kebijakan dan tindakan yang konsisten yang akan menentukan bahwa sumber daya manusia sebuah perusahaan meliputi, pengetahuan, ketrampilan dan kemampuan kolektif pekerja, turut menyumbang terhadap pencapaian kinerja perusahaan (Balrd \& Meshoulam, 1988; Jackson \& Schuler, 1995).

Sedangkan menurut (Arthur, 1994; Cuttcher \& Gershenfield, 1991; Huselid, 1995; Huselid \& Becker, 1996; Macpuffie, 1995) hal mendasar dari perspektif strategis manajemen sumber daya manusia adalah asumsi bahwa keberhasilan sebuah perusahaan dipengaruhi oleh tindakan manajemen sumber daya manusia yang dimiliki oleh perusahaan tersebut.

Sejumlah tulisan tentang strategi manajemen sumber daya manusia menekankan signifikansi manajemen sumber daya manusia dan sumber daya manusia sebagai sumber keunggulan kompetitif (Barney, 1991; Pfeffer, 1994; Snell, Youndt, \& Wright, 1996; Lawler, 1991). Bersama-sama, mereka menunjukkan bahwa penekanan yang lebih besar seharusnya diberikan pada pengembangan modal sumber daya manusia. Hal ini 
dikarenakan semakin banyak manajemen percaya bahwa manajemen sumber daya manusia memberikan andil bagi keberhasilan perusahaan, semakin terintegrasi perannya dalam proses perencanaan strategik perusahaan (Butler, Ferros \& Napier, 1991). Menurut Lewin dan Yang (1992), nilai manajemen sumber daya manusia juga memiliki dampak pada bermacam kebijakan manajemen sumber daya manusia.

Berpijak pada kenyataan itu, maka misi organisasi perusahaan selain berorientasi pada pelayanan yang efektif juga menata manajemen sumber daya manusia yang berorientasi pada peningkatan kualitas, kemampuan, dan kesejahteraan manusianya. Namun demikian peningkatan peran dan kualitas sumber daya manusia belum menjamin peningkatan kinerja perusahaan, selama praktek dan kebijakan manajemen sumber daya manusia/hubungan industrial perusahaan belum dapat memberikan keadilan dan kesejahteraan pekerja (Fuad Mas'ud, 1997).

Schuler (1990) dalam satu tulisan ilmiahnya, mencoba menjawab keraguan terhadap fungsi manajemen sumber daya manusia dengan mengajukan pendapat bahwa manajemen sumber daya manusia perlu melakukan transformasi dari sebuah fungsi sosial yang terfokus pada kegiatan administrasi kepegawaian semata, menuju kearah sebuah team kerjasama antara manajer sumber daya manusia dengan manajer-manajer lini yang lain, khususnya dalam menangani isu bisnis yang berkaitan dengan peran sumber daya manusia.

Perubahan paradigma bisnis menuntut adanya perubahan dalam pengelolaan kegiatan perusahaan. Salah satu dimensi kegiatan perusahaan yang memerlukan pendekatan baru dalam pengelolaannya adalah manajemen sumber daya manusia. Pandangan lama tentang manajemen sumber daya manusia harus ditinggalkan dan diganti dengan pandangan baru. Pandangan lama melihat sumber daya manusia bukan dalam kedudukan yang vital, sedangkan pandangan baru melihat sumber daya manusia sebagai sesuatu aspek vital dalam perusahaan (Djamaludin Ancok, 2002).

Ulrich (1996) memberikan suatu konsep persamaan peran manajemen sumber daya manusia sebagai business partner tidak hanya sebagai pengelola administrative saja, tetapi juga sebagai mitra strategis (strategic partner), sebagai pakar administrasi 
(Administative Expert), pakar karyawan (employee champion) dan sebagai agen perubahan (change agent).

Dan apabila agenda yang akan datang dalam hal penciptaan nilai (creating value) datangnya dari sumber daya manusia, maka peran terbaru dari manajemen sumber daya manusia perlu didefinisikan lebih lanjut. Menurut Ulrich (1996) beberapa tahun belakangan ini peran manajemen sumber daya manusia telah mengalami pergeseran, yang sering digambarkan dalam terminologi transisi, sebagai berikut ;

- Operasi ke strategis

- Kualitatif ke kuantitatif

- Pengawasan ke kemitraan

- Jangka pendek ke jangka panjang

- Administratif ke konsultatif

- Berorientasi fungsional ke berorientasi bisnis

- Terfokus secara internal ke konsumen dan secara eksternal

- Reaktif ke proaktif

- Terfokus aktivitas ke terfokus solusi

Seharusnya pakar manajemen sumber daya manusia dapat memainkan peran sebagai peran operasional maupun peran strategis, mereka bertindak sebagai penetap kebijakan sekaligus mitra dan dapat bertanggungjawab terhadap tujuan yang bersifat kualitatif maupun kuantitatif dari sasaran jangka pendek ataupun jangka panjang perusahaan.

Apabila semua faktor potensial baik eksternal maupun internal seperti diuraikan diatas telah di manage dengan baik, maka manajemen sumber daya manusia akan menjadi instrumen strategis untuk men-support tercapainya kinerja perusahaan yang ditetapkan. Dalam perspektif ini, kebijakan dan praktek manajemen sumber daya manusia merupakan aktifitas semua unit fungsional organisasi, bukan hanya fungsi bidang sumber daya manusia saja. Didalam pendekatan strategi manajemen sumber daya manusia, setiap manajer adalah manajer sumber daya manusia (Anthony et al, 1996). Keterkaitan dan kebersamaan dengan fungsi lain dalam organisasi tersebut menggeser 
keberadaan dan domain bidang sumber daya manusia menjadi multifunctional dan interfunctional.

Salah satu hal yang sering menjadi isu sentral penyebab tidak tercapainya kinerja pelayanan yang sesuai dengan harapan pelanggan adalah strategi di bidang manajemen sumber daya manusia. Berkaitan dengan hal tersebut maka beberapa upaya perlu dilakukan secara sungguh-sungguh, di antaranya melalui reposisi peran manajemen sumber daya manusia agar tidak terkesan hanya berperan sebagai unit pelaksana administrasi karyawan saja, namun harus berperan sebagai business partner perusahaan.

Beberapa peran baru tersebut dapat dikategorikan sebagai peran strategis sumber daya manusia karena terkait langsung secara aktif dengan kegiatan bisnis perusahaan. (Schuller \& Hauber, 1993). Ulrich (1991; 1997 dan 1998) dalam (Ignatius R.S, 2002) melihat kategorisasi peran strategis sumber daya manusia meliputi hal sebagai berikut :

- Menjadi parner manajer dalam pelaksanaan strategi, artinya manajer sumber daya manusia mampu untuk melakukan audit organisasional, menemukan metode pengembangan yang tepat dan melakukan prioritas dalam penentuan skala serta pelaksanaan tindakan.

- Menjadi eksekutif administrasi yang ahli, artinya manajer sumber daya manusia tentunya bkan hanya terampil dalam pekerjaan administrasi belaka, tetapi juga terampil dalam pekerjaan manajerial yang membutuhkan pengambilan keputusan yang tepat, cepat dan benar.

- Menjadi eksekutif yang juara, artinya mampu menjadi panutan bagi karyawan lain dalam bekerja dan fasilitator serta motivator jika karyawan lain mengalami kesulitan. Menjadi agen perubahan, artinya menjadi innovator dalam arti memberikan nilai tambah bagi kemajuan organisasi dalam mengantisipasi perubahan lingkungan bisnis yang terjadi di sekitarnya (Corner \& Ulrich, 1996 dalam Ignatius R.R, 2002)

\section{Manajemen Sumber Daya Manusia}


Penelitian dalam bidang pengembangan peran manajemen sumber daya manusia hampir secara eksklusif telah dilaksanakan di dunia barat. Para peneliti telah mengeksplorasi dampak strategi bisnis organisasional pada strategi manajemen sumber daya manusia (Arthur, 1992), dampak strategi manajemen sumber daya manusia pada kinerja perusahaan (Arthur, 1994, Huselid, 1995; Huselid, Jackson \& schuler, 1997; Lawler, Andersen \& Buckler, 1995). Para peneliti terdahulu secara khusus menitikberatkan pada bagaimana perubahan-perubahan dalam praktek manajemen sumber daya manusia mempengaruhi kinerja perusahaan, sedangkan para peneliti berikutnya mulai mempertanyakan bagaimana karakteristik organisasional membentuk prioritas dan praktek manajemen sumber daya manusia (Jackson, S.E, \& Schuler, R.S, 1995, Onsardi, 2019, Arkat, F., 2020).

Penelitian-penelitian teoritis lain membenarkan pandangan Huselid, bahwa stategistrategi manajemen sumber daya manusia partisipasi tinggi dapat meningkatkan, memperkokoh dan mempertahankan kompetensi dan komitmen pegawai, aspek yang penting bagi keunggulan kompetitif dalam menghadapi situasi bisnis masa kini (Lado \& Wilson, 1994; Ulrich, 1998; Ulrich \& Lake, 1990 dalam Bae J \& John, 2000).

Disamping itu strategi manajemen sumber daya manusia partisipasi tinggi memberikan kompleksitas sosial dan ambiguitas kausal yang lebih tinggi, yang akan menumbuhkan keunggulan kompetitif melalui pembentukan batasan-batasan tiruan (Lado \& Wilson, 1994; Snel dkk, 1996 dalam Bae J \& John, 2000). Strategi-strategi manajemen sumber daya manusia partisipasi tinggi menempatkan perusahaan pada posisi untuk menciptakan pengetahuan dan peluang-peluang, yang membuat perusahaan menjadi lebih dinamis, fleksibel, tangkas, sehingga perusahaan dapat beradaptasi lebih baik terhadap perubahan lingkungan yang tidak menentu (Nonaka, 1998; Teece, Pisano \& Shuen, 1997 dalam Bae J \& John, 2000)

\section{Kinerja Pelayanan}

Kinerja pelayanan yang dimaksud dalam penelitian ini adalah kinerja perusahaan yang dilihat dari sisi kinerja manajemen sumber daya manusia saja (dengan 
mengabaikan kinerja keuangan) yang meliputi : kemampuan dalam hal memberikan rasa puas kepada karyawan, kemampuan dalam menumbuhkan komitmen dan loyalitas karyawan terhadap perusahaan (seperti kualitas kecepatan pelayanan kepada konsumen), kemampuan untuk menjaga tingkat keandalan dan kontinyuitas dalam pensuplaian tenaga listrik (imej publik), kemampuan untuk menyediakan tenaga listrik dengan mutu memenuhi persyaratan standar (kualitas produk), dan kemampuan dalam hal meningkatkan produktivitas kerja karyawan (Asmawi, 2017, Onsardi, 2018 \& 2019, Anjani, 2019, Putri, S. H.,2020).

Salah satu permasalahan utama dalam penilaian hubungan sebab akibat dari sistem manajemen sumber daya manusia dan kinerja perusahaan, adalah masalah kesinambungan antara dua variabel (Huselid, 1995). Selalu dikatakan bahwa perusahaan yang berkinerja baik cenderung memiliki praktek manajemen sumber daya manusia yang lebih baik.

Untuk mengukur kinerja perusahaan dapat dilihat dari dua sisi yaitu sisi finansial dan sisi kinerja sumber daya manusia (Tai Wai, Chin Huat \& Chau Fuat, 2000). Penelitian ini mengukur kinerja perusahaan dengan melihat pada sisi kinerja sumber daya manusia saja, karena perusahaan biasanya enggan untuk mengungkapkan kinerja finansial mereka (Tai Wai, Chin Huat \& Chau Fuat, 2000). Dimensi pengukuran kinerja perusahaan menurut Khandwallaa, (1977) dalam Tai Wai, Chin Huat \& Chau Fuat, (2000), yaitu : (1) kepuasan kerja karyawan, (2) komitmen atau loyalitas karyawan terhadap perusahaan, (3) niat baik dan imej publik, (4) kualitas produk, (5) produtivitas karyawan.

Dimensi pengukuran ini juga didukung oleh Wright dan McMahan (1992) dan Onsardi (2019) yang menjelaskan bahwa kinerja perusahaan dapat dilihat dari kinerja manajemen sumber daya manusia seperti : sikap karyawan dan produktivitas kerja perusahaan. 


\section{Konsep Manajemen Sumber Daya Manusia}

Manajemen sumber daya manusia adalah sebagai suatu perencanaan, pengorganisasian, pengarahan, dan pengawasan atas pengadaan, pengembangan kompensasi, pengintegrasian, pemeliharaan, dan pemutusan hubungan kerja dengan maksud untuk mencapai tujuan organisasi perusahaan secara terpadu (Husein Umar, 2000). Batasan yang lebih rinci dan operasional dikemukan oleh (Flippo, dalam Soekidjo N, 1989) yaitu, manajemen sumber daya manusia adalah perencanaan, pengorganisasian, pengarahan dan pengawasan kegiatan-kegiatan pengadaan, pengembangan, pemberian kompetensi, pengintegrasian, pemeliharaan, dan pelepasan sumber daya manusia agar tercapai berbagai tujuan individu, organisasi dan masyarakat.

Manajemen sumber daya manusia mempunyai kekhususan bila dibandingkan dengan manajemen secara umum atau manajemen sumber daya lain, karena yang di manage adalah manusia, sehingga keberhasilan atau kegagalan manajemen sumber daya manusia ini akan mempunyai dampak yang sangat luas. Manajemen sumber daya manusia adalah merupakan suatu pengakuan terhadap pentingnya sumber daya manusia atau tenaga kerja dalam organisasi. Manajemen sumber daya manusia diperlukan untuk meningkatkan daya guna dan hasil guna sumber daya manusia dalam organisasi, dengan tujuan untuk memberikan kepada organisasi suatu satuan kerja yang efektif.

Adapun tujuan utama dari manajemen sumber daya manusia adalah untuk meningkatkan kontribusi sumber daya manusia (karyawan) terhadap organisasi dalam rangka mencapai produktivitas organisasi yang bersangkutan.

\section{Perubahan Peran Manajemen Sumber Daya Manusia}

Dalam banyak praktek bisnis isu-isu sumber daya manusia masih cenderung diabaikan. Keunggulan kompetitif (competitive advantage) biasanya dibahas dalam konteks perencanaan strategic yang menekankan pada analisis industri dan persaingan, kebutuhan pelanggan, atribut produk/jasa, dan kapabilitas manufacturing, dengan meletakan isu-isu sumber daya manusia hanya di latar belakang saja. Bahkan Porter (1985), dalam pendekatan value chain yang sangat terkenal, memperlakukan manajemen 
sumber daya manusia hanya sebagai suatu kegiatan pendukung. Pertanyaan yang muncul : Apakah mungkin manajemen sumber daya manusia memainkan peran atau fungsi yang penting ? atau Apakah system manajemen sumber daya manusia dapat dipertimbangkan sebagai kegiatan penambah nilai yang utama ? Jawaban terhadap pertanyaanpertanyaan tersebut tergantung pada seberapa besar manajemen sumber daya manusia dapat memberikan kontribusi terhadap pengembangan keunggulan kompetitif yang berkelanjutan. Bila system manajemen sumber daya manusia bisa menciptakan keunggulan kompetitif nyata, maka manajemen sumber daya manusia harus diintegrasikan secara penuh dalam tahap-tahap baik formulasi maupun implementasi proses manajemen strategic.

Semakin disadari bahwa keunggulan kompettif yang sulit dicopy dan sustainable adalah melaui kegiatan-kegiatan dan praktik-praktik manajemen sumber daya manusia perusahaan. Pengembangan keunggulan kompetitif melalui praktik-praktik mnajemen sumber daya manusia dapat dilakukan dengan pemahaman strategic targets dan strategic thrusts (Schuler \& Macmillan, 1984) dalam T. Hani Handoko (2002).

Perubahan lingkungan bisnis akan membawa dampak perubahan pada strategi bisnis. Sebagaimana telah diketahui perubahan strategi bisnis akan semakin mengarahkan manajer utuk memperjelas ke arah mana visi dan misi bidang sumber daya manusia akan dibawa. Dalam pengertian bahwa sumber daya manusia merupakan bagian tidak terpisahkan dari organisasi (Golden \& Ranunanjam, 1985) . Karena perubahan ini menyangkut banyak aspek dan tuntutan yang harus dicapai, maka perlu dilakukan pengembangan kualitas pelaksanaan sumber daya manusia melalui kegiatan investasi sumber daya manusia. Perlu diketahui bahwa dengan adanya investasi sumber daya manusia maka pola strategi manajemen sumber daya manusia akan berubah dan menuntut perubahan tipe kompetensi pada tugas yang berbeda yang akan berdampak pada perubahan peran manajemen sumber daya manusia (Schuller \& jacson, 1996). Terkait dengan perubahan peran sumber daya manusia maka perlu dilihat peran manajemen sumber daya manusia pada paradigma tradisional. Pada paradigma tradisional organisasi hanya menganggap sumber daya manusia hanya sebagai 
pelengkap saja, sehingga peran utama dari manajemen sumber daya manusia tidak lain hanya untuk mengurus administrasi kepegawaian belaka (Cascio, 1995).

Dalam hal ini (Cascio, 1995) menggarisbawahi beberapa peran manajemen sumber daya manusia yang dilakukan pada paradigma lama seperti : (1) Attraction, yang meliputi : identifikasi persyaratan pekerjaan, menentukan jumlah orang dan kombinasi ketrampilan yang dibutuhkan untuk suatu pekerjaan serta menyediakan kesempatan yang sama bagi setiap kandidat terpilih. (2) Selection, yang meliputi : memilih orang terbaik bagi pekerjaan yang bersangkutan. (3) Retention, yang meliputi : memberikan reward bagi orang yang bekerja efektif dan mempertahankan keamanan dan kenyamanan lingkungan kerja. (4) Development, yang meliputi ; meningkatkan dan menyiapkan kompetensi karyawan melalui peningkatan Knowledge, skill dan abilities dan pendekatan spesialis fungsi perusahaan. (5) Assestment, yang meliputi : pengamatan dan penilaian perilaku dan sikap yang relevan dengan pekerjaan dan kinerja sumber daya manusia. (6) Adjustment, yang meliputi ; pemeliharaan pemenuhan kebutuhan yang terkait dengan kebijakan sumber daya manusia perusahaan. Pemahaman peran manajemen sumber daya manusia secara tradisional (Cascio, 1995) akan berakibat pada dipakainya struktur organisasi sentralistik, dimana keterlibatan dari manajer lini sangat terbatas dan kemudian tipe perencanaan dari atas ke bawah (top-down) yang memiliki kelemahan karena tidak ada komunikasi dua arah dan keterlibatan karyawan dalam proses perencanaan bisnis sangat terbatas (Blackburn \& Rossen, 1993) dalam (Ignatius R.S, 2002).

Sementara itu Schuller (1990) dalam (Ignatius R.S, 2002) melihat berbagai macam peran baru manajemen sumber daya manusia sebagai hasil proses repositioning seperti : (1) Business person melputi : praktisi sumber daya manusia, partisipasi dalam bidang keuangan dan operasional, rotasi posisi antar fungsi sumber daya manusia dan fungsi lain. (2) Shaper of change seperti : partisipasi tim atas perubahan, melakukan penelitian, dan partisipasi aktif pembentukan misi dan tujuan perusahaan. (3) Consultant to organizer or partner to line seperti : aktif dalam konsorsium penyiapan proposal dan partisipasi dalam system komputerisasi. (4) Strategy formulator and 
implementor seperti : mengerti strategi bisnis, orientasi bisnis secara strategis, strategi semua divisi organisasi dan aplikasi praktek manajemen sumber daya manusia dari berbagai lini strategis. (5) Talent manager seperti : komunikasi dengan semua manajer lini secara terus-menerus, konferensi pengembangan jaringan kerja dan computer intillegent. (6) Asset manager and cost controller seperti ; kursus akuntansi dan keuangan, baca artikel jurnal dan prosedur akuntansi perusahaan .

\section{Peran Ganda Manajemen Sumber Daya Manusia}

Seperti yang sudah dikemukan oleh Ulrich (1996) bahwa agenda yang akan datang (next agenda) dalam hal penciptaan nilai (creating value) datangnya dari sumber daya manusia, maka peran terbaru dari manajemen sumber daya manusia perlu didefinisikan lebih lanjut. Randall \& Susan (1996) menyatakan bahwa perusahaan yang efektif dalam lingkungan persaingan yang sangat tinggi sekarang ini akan mendorong departemen sumber daya manusia mereka untuk memainkan banyak peran. Ulrich lebih jauh melihat peran ganda dalam suatu kerangka kerja (frame work) seperti terlihat dalam gambar 1, yang terdiri dari empat peran kunci yang mesti dipenuhi oleh manajemen sumber daya manusia, agar kemitraannya dengan bisnis perusahaan dapat menjadi suatu realita. 
Gambar 1.1 : Peran ganda Manajemen Sumber Daya Manusia

FOKUS STRATEGIS / MENDATANG

\begin{tabular}{|c|c|c|c|}
\hline & $\begin{array}{l}\text { Manajemen } \\
\text { sumber daya } \\
\text { manusia } \\
\text { strategis }\end{array}$ & $\begin{array}{l}\text { Manajemen } \\
\text { transformasi } \\
\text { dan perubahan }\end{array}$ & SUMBER \\
\hline & $\begin{array}{l}\text { Manajemen } \\
\text { infrastruktur } \\
\text { perusahaan }\end{array}$ & $\begin{array}{l}\text { Manajemen } \\
\text { kontribusi } \\
\text { karyawan }\end{array}$ & MANUSIA \\
\hline
\end{tabular}

\section{FOKUS HARIAN / OPERASIONAL}

Sumber : Ulrich, D (1996), " Human Resource Champion ; The Next Agenda for Adding Value and Delivering Results", Harvard Business School Press, Boston, Massachusetts.

Dari gambar 1 dapat dijelaskan, dua sumbu memperlihatkan fokus dan activities dari pakar manajemen sumber daya manusia . Sumbu fokus menunjukkan pola jangka panjang/operasional. Pakar manajemen sumber daya manusia harus mempelajari baik strategi maupun operasional dengan fokus kepada jangka panjang maupun jangka pendek. Sumbu activities berkisar dari pengelolaan process ke pengelolaan people. Kedua sumbu ini menggambarkan empat prinsip peran Sumber Daya Manusia, yaitu (1) management of strategic human resources; (2) management of firm infrastructure; (3) management of the employee contribution; (4) management of transformation and change.

Untuk dapat mengerti masing-masing peran ini secara lebih jauh, harus mempertimbangkan masing-masing ketiga hal ini, yaitu deliverables / outcome yang akan membentuk hasil dari peran tersebut, karakteristik metaphor atau citra visual yang mengikuti peran tersebut dan activities dimana pakar manajemen sumber daya manusia harus memainkan perannya untuk tercapainya peran yang dimaksud. 


\section{Tabel 2.1 : Definisi Peran Sumber Daya}

\begin{tabular}{|c|c|c|c|}
\hline Peran & $\begin{array}{c}\text { Kemampuan } \\
\text { penyampaian / } \\
\text { hasil }\end{array}$ & Metafora & Aktivitas \\
\hline $\begin{array}{l}\text { Manajemen } \\
\text { mengenai sumber } \\
\text { daya manusia } \\
\text { strategis }\end{array}$ & $\begin{array}{l}\text { Pelaksanaan } \\
\text { strategi }\end{array}$ & Mitra strategis & $\begin{array}{l}\text { Penyesuaian } \\
\text { kinerja perusahaan } \\
\text { dan SDM : } \\
\text { "Diagnosa } \\
\text { organisasional" }\end{array}$ \\
\hline $\begin{array}{l}\text { Manajemen } \\
\text { mengenai } \\
\text { infrastruktur } \\
\text { perusahaan }\end{array}$ & $\begin{array}{l}\text { Pembangunan } \\
\text { infrastruktur yang } \\
\text { efisien }\end{array}$ & Pakar administrasi & $\begin{array}{l}\text { Reengineering } \\
\text { proses organisasi } \\
\text { "Layanan } \\
\text { bersama" }\end{array}$ \\
\hline $\begin{array}{l}\text { Manajemen } \\
\text { mengenai kontribusi } \\
\text { karyawan }\end{array}$ & $\begin{array}{l}\text { Peningkatan } \\
\text { komitmen dan } \\
\text { kemampuan } \\
\text { karyawan }\end{array}$ & Pakar karyawan & $\begin{array}{l}\text { Mendengarkan dan } \\
\text { merespon terhadap } \\
\text { karyawan : } \\
\text { "Memberikan } \\
\text { sumber bagi } \\
\text { karyawan }\end{array}$ \\
\hline $\begin{array}{l}\text { Manajemen } \\
\text { mengenai } \\
\text { transformasi dan } \\
\text { perubahan }\end{array}$ & $\begin{array}{l}\text { Pembahuruan } \\
\text { organisasi }\end{array}$ & Agen perubahan & $\begin{array}{l}\text { Mengatur } \\
\text { transformasi dan } \\
\text { perubahan : } \\
\text { "Memastikan } \\
\text { kapasitas untuk } \\
\text { berubah" }\end{array}$ \\
\hline
\end{tabular}

Sumber : Ulrich, D (1996), “ Human Resource Champion ; The Next Agenda for Adding

Value and elivering Results", harvard Business School Press, boston, Massachusetts. 
Adapun deskripsi dari peran manajemen sumber daya manusia sebagaimana dijelaskan oleh Ulrich (1996) adalah :

\section{Peran Sebagai Mitra Strategis}

Kondisi dimana pakar manajemen sumber daya manusia memainkan peranan sebagai mitra strategis (strategic partner) jika mereka mampu mengimplementasikan strategi bisnis kedalam tindakan nyata. Sebagai mitra strategis, pakar manajemen sumber daya manusia bekerja sama dengan manajer-manajer lini (line managers) untuk mengadakan dan mengelola suatu proses yang membuat organisasi dapat memenuhi persyaratan bisnis.

Penerapan strategi bisnis kedalam tindakan nyata memerlukan apa yang disebut Ulrich sebagai diagnose organisasi (organizational diagnosis). Diagnose organisasi merupakan sistem penilaian (assessment) dan penggabungan praktek organisasi dengan tujuan bisnis. Diagnosis organisasi dapat dibentuk pada setiap level perusahaan, baik itu pada level bawah, menengah, maupun atas. Pada tingkat korporat, pakar manajemen sumber daya manusia bersama-sama dengan komite eksekutif perusahaan dapat melakukan diagnosis melalui penilaian organisasi yang didasarkan pertanyaan bisnis. Analisis serupa dapat diterapkan di dalam pabrik, unit bisnis, atau bagian fungsional seperti litbang, pemasaran atau sumber daya manusia.

\section{Peran Sebagai Pakar Administrasi}

Kondisi dimana manajer lini dengan pakar manajemen sumber daya manusia secara bersama-sama berupaya untuk mencari solusi agar lebih efisien dalam melakukan pekerjaan. Upaya ini dapat dilakukan dengan rekayasa kembali (reengineering), termasuk merekayasa kembali dalam bidang sumber daya manusia. Sebagai pakar manajemen sumber daya manusia merekayasa kembali kualitas layanan dan menjadi pakar administrasi dengan membuat infrastruktur lebih efisien, baik dalam proses 
sumber daya manusia maupun dalam bisnis secara keseluruhan. Jadi intinya dengan rekayasa kembali itu, administrasi menjadi efisien.

Menjadi pakar administrasi perlu menguasai dua fase rekayasa kembali. Fase pertama, yaitu proses perbaikan, memfokuskan pada identifikasi proses-proses yang tidak efektif dan merencanakan metode alternatif untuk meningkatkan kualitas layanan. Dalam fase pertama, pakar manajemen sumber daya manusia mempelajari bagaimana “melangsingkan”, mengotomatisasikan, dan memperbaiki efisiensi praktek sumber daya manusia. Kondisi ini makin dipermudah dengan hadirnya teknologi yang membuat pekerjaan makin mudah dan efisien.

Fase kedua, yaitu memikirkan pencipta nilai (rethinking value creation), merupakan fase yang lebih penting. Dalam proses penciptaan nilai, menurut Ulrich, dimulai dari kesadaran bahwa pencipta nilai itu tidak terjadi dalam suatu kelompok, tetapi terjadi dengan adanya interaksi dengan orang diluar kelompok yang saling berinteraksi, misalnya pelanggan. Nilai (value) ditentukan oleh penerima (receiver) bukan oleh pemberi layanan. Pakar manajemen sumber daya manusia sebagai pakar

administrasi hendaknya mempelajari bagaimana menciptakan nilai yang bermakna bagi manajer lini, bukan bagi manajemen sumber daya manusia sendiri. Untuk itu, pakar manajemen sumber daya manusia dapat memulai dengan pertanyaan "nilai apa yang dapat saya ciptakan dalam organisasi bisnis ini ". Dengan memulai dari pertanyaan itu, berarti pakar manajemen sumber daya manusia sudah mengubah fokus kerja dari apa yang dapat dilakukan menjadi apa yang harus dihasilkan.

\section{Peran Sebagai Pakar Karyawan}

Kondisi dimana manajer lini dan pakar manajemen sumber daya manusia berupaya untuk mengembangkan kontribusi karyawan secara optimal untuk mencapai kinerja perusahaan. Dalam dunia yang makin terbuka, tingkat persaingan bisnis juga makin meningkat. Pengusaha makin mobile meluaskan jaringan bisnisnya, bukan hanya di dalam negeri tetapi juga di luar negeri. Dalam kondisi demikian, tuntutan pengusaha terhadap karyawan juga makin tinggi. Karyawan yang cakap tentu tidak terpengaruh 
oleh adanya ekspansi perusahaan, karena mereka dengan cepat dapat menyesuaikan diri. Tapi bagi karyawan yang kurang cakap, kondisi ini menyebabkan karyawan menjadi depresi. Karena itu, menjadi kewajiban manajer dan terutama pakar manajemen sumber daya manusia membantu karyawan yang kurang bisa menyesuaikan dengan tuntutan perusahaan.

Untuk itu, Ulrich (1996) menyarankan tiga hal yang perlu diperhatikan oleh manajer lini dan pakar manajemen sumber daya manusia. Pertama, kurangi tuntutan (demand), yaitu dengan cara mengurangi beban kerja dan menyeimbangkan dengan sumber daya yang dimiliki karyawan. Kedua, tingkatkan sumber daya, yaitu membantu karyawan mengidentifikasikan sumber daya baru sehingga mereka dapat menyesuaikan dengan kebutuhan perusahaan. Ketiga, mengubah tuntutan (demand) menjadi sumber daya, yaitu dengan cara membantu karyawan mempelajari transformasi demand ke dalam sumber daya (resource).

Selain itu menurut Ulrich, pakar manajemen sumber daya manusia harus menunjukan kepada karyawan kepercayaan dan keyakinan, kepekaan psikologis (the sensitivity of psychologist), kreativitas seni, dan disiplin tinggi. Untuk mengembangkan kontribusi karyawan, pakar manajemen sumber daya manusia bekerja sama dengan manajer lini meyakinkan karyawan bahwa mereka dapat memenuhi harapan karyawan, baik dalam karir, suasana kerja ataupun dalam reward.

\section{Peran Sebagai Agen Perubahan}

Kondisi dimana pakar manajemen sumber daya manusia sebagai agen perubahan harus dapat mengembangkan kapasitas yang ada di perusahaan, melalui perubahan-perubahan yang efektif dan optimal. Persaingan yang semakin tajam mendorong pengembangan inovasi-inovasi baru agar dapat memenangkan persaingan. Menurut ulrich, ada tiga tipe perubahan yang harus ditanggapi oleh pakar manajemen sumber daya manusia, yaitu inisiatif, proses, atau prosedur baru.

Pertama, perubahan inisiatif memfokuskan pada penerapan program, proyek atau prosedur baru. Beberapa perubahan seperti perubahan struktur organisasi baru, 
upaya peningkatan pelayanan, upaya perbaikan kualitas dan program pengurangan biaya hampir terjadi setiap tahun di banyak perusahaan. Melalui strategi perencanaan, inisiatif khusus diterapkan sebagai bagian upaya perbaikan proses manajemen. Kedua, perubahan proses dalam perusahaan memfokuskan pada cara bagaimana melakukan kerja secara optimal. Perusahaan dapat melakukan perubahan proses dengan cara mengidentifikasikan proses inti dan kemudian memperbaiki proses tadi dengan melalui penyederhanaan kerja, penilaian nilai tambah, dan upaya-upaya rekayasa kembali (reengineering). Ketiga, perubahan budaya dalam perusahaan akan terjadi jika strategi dasar organisasi bisnis dikonseptualkan kembali.

Pakar manajemen sumber daya manusia sebagai agen perubahan dapat mengembangkan kapasitas yang ada di perusahaan untuk menangani ketiga tipe perubahan tadi. Mereka harus dapat meyakinkan bahwa inisiatif telah ditentukan, dikembangkan, dan dilaksanakan secara tepat waktu, bahwa proses telah dihentikan, dimulai atau disederhanakan dan bahwa nilai fundamental di dalam organisasi telah didiskusikan dan diadaptasikan kedalam kondisi bisnis.

Seperti telah didiskusikan diatas dan digambarkan pada gambar 1 bahwa pakar manajemen sumber daya manusia dapat memberikan nilai tambah terhadap kinerja pelayanan, dilihat dari sisi kinerja manajemen sumber daya manusia, dengan empat cara, yaitu : mereka dapat membantu terlaksananya strategi (execute strategy), membangun infrastruktur (build infrastructure), menjamin adanya kontribusi dari karyawan (employee contribution), serta dapat mengelola transformasi dan perubahan yang terjadi (manage transformation end change). 


\section{BAB II \\ FAKTOR-FAKTOR YANG BERPENGARUH \\ TERHADAP KEPUASAN KERJA}

\section{Latar Belakang}

Banyak organisasi menjalankan berbagai program peningkatan kualitas dalam berbagai aspek aktivitas organisasi mengalami kegagalan, yang disebabkan tidak adanya usaha untuk merubah kinerja organisasi (Goetch dan Davis, 1994 dalam Arifin, 1997). Di samping itu kualitas organisasi sendiri akan sangat tergantung pada kualitas sumber daya manusia sebagai pekerja atau pelaku layanan dalam suatu organisasi (Zeithaml et al, 1994). Sebaik apapun strategi yang dirumuskan oleh pimpinan, jika tidak mendapatkan dukungan dari karyawan, maka strategi itu tidak akan dapat dilaksanakan bila tidak disertai sikap positif dari pekerjaanya dan disertai komitmen penuh dari pekerja (Crammer, 1996).

Kepuasan kerja akan sangat mempengaruhi pekerja untuk bekerja produktif dengan motivasi internal yang baik, karena kepuasan kerja dapat menciptakan sikap dan menunjang perilaku baik pekerja (Ma'mun dan Dewabrata, 1995). Dalam situasi dan kondisi Indonesia akhir-akhir ini, dengan terjadinya krisis diberbagai sektor juga diduga mempengaruhi sikap dan perilaku karyawan dalam bekerja. Faktor-faktor situasional akan mempengaruhi sikap pekerja (Ganzach, 1998). Menurut Frone, Russell \& Cooper (1994) ada beberapa faktor yang dapat mempengaruhi kepuasan kerja karyawan yaitu faktor tekanan pekerjaan, faktor keterlibatan pekerjaan dan faktor konflik keluargapekerjaan, dan faktor dukungan sosial (Parasuraman, Greenhaus \& Granrose, 1992, Onsardi, 2002).

Tekanan pekerjaan yang berupa pemberian tugas yang berat kepada karyawan dapat mempengaruhi kondisi kerja seorang karyawan yang akan berakibat kepada kurang puasnya karyawan tersebut dalam melaksanakan pekerjaannya. Tekanan pekerjaan dapat muncul dari interaksi individu dengan pekerjaannya yang dicirikan dengan perubahan-perubahan di dalam individu tersebut didorong dari fungsi normal 
(Beehr \& Newman dalam Luthans, 1995). Selain itu pula tekanan pekerjaan dapat terjadi karena ketidakseimbangan antara tuntutan pekerjaan dengan kemampuan seseorang untuk memenuhi kebutuhan, termasuk disini pengembangan karier, upah yang diterima dan kenyaman fisik (Frone, Russell \& Cooper, 1994 dan Rini, 2001).

Lingkungan kerja yang tidak kondusif akan dapat memicu munculnya tekanan pekerjaan. Beberapa faktor lingkungan yang dapat menimbulkan tekanan pekerjaan yaitu :

1. Kararakteristik lingkungan kerja seperti kebisingan, kesepian yang sangat, panas atau dingin yang berlebihan, penerangan kerja yang kurang, tempat kerja yang lembab dan sebagainya (Howarth \& Gilham, 1992).

2. Kararkteristik tugas misalnya beban kerja dan target produksi yang tinggi dan pekerjaan yang repetitif (Howarth \& Gilham, 1992).

3. Karakteristik peran misalnya beban pekerjaan yang berat, ketidak jelasan peran dalam pekerjaan, campur tangan atasan dalam hal kewenangan (Frone, Russell \& Cooper, 1994).

4. Lingkungan psikososial dalam organisasi, meliputi tugas, peran dan tanggugjawab yang tidak jelas, promosi dan kesempatan untuk mengembangkan inisiatif yang terbatas (Howarth \& Gilham, 1992).

5. Kararakteristik lingkungan sosial misalnya hubungan antar karyawan, karyawan dengan bawahan maupun atasan, kontrol terhadap lingkungan kerja (Marshal, Warr \& Wall dalam Darmawan, 1993).

Keterlibatan pada pekerjaan berpangaruh terhadap sikap dan perilaku kerja. Menurut Kanungo (1979) terterlibatan pekerjaan mempengaruhi intensitas kerja., sedangkan perilaku kerja dengan tingkat keterlibatan pekerjaan yang tinggi akan mengurangi kemungkinan turn over, kemangkiran, dan kelambanan, serta jam yang digunakan untuk bekerja meningkat (Mtchell, 1985, Onsardi, 2002). Tingkat keterlibatan pekerjaan yang tinggi berperan dalam membentuk kinerja, menambah kualitas dan kuantitas hasil kerja (Katz \&Kahn, 1978), efesiensi kerja yang tinggi ( Yoder, 1979) serta dapat memunculkan kepuasan kerja (Frone, Russell \& Cooper, 1994). Beberapa 
penelitian menyatakan, semakin tinggi keterlibatan pekerjaan, maka akan tinggi kepuasan kerja (Frone, Russell \& Cooper; 1992, Yasin, 1999, Rini, 2001). Kondisi keterlibatan pekerjaan yang tinggi berhubungan dengan kondisi positif bagi individu sebagai karyawan yaitu semangat, prestasi, kepuasan, kuantitas dan kualitas, efesiensi, banyaknya kerja dalam jam kerja, serta berkurangnya tingkat absensi serta turn over (Mtchell, 1985 dalam Djawa, 1993, Onsardi, 2018). Kondisi positif tersebut mendorong timbulnya sikap dan perilaku kerja yang bermanfaat atau menguntungkan organisasi dan karyawan. Individu yang terlibat pada pekerjaan menunjukan kondisi berpartisipasi dalam proses pengambilan keputusan yang mempengaruhi dirinya, sehingga cenderung puas pada pekerjaan. Akibat selanjutnya individu memandang pekerjaannya mampu membangkitkan semangat kerjanya dan meningkatkan kepuasan kerja (Marshal, Warr \& Wall Darmawan, 1993).

Konflik peran merupakan simultan dari dua atau lebih peran yang diharapkan, sehingga pemenuhan peran yang satu akan menghalangi peran yang lain (Katz \& Kahn, 1978). Konflik peran terjadi pada seorang individu dimana dia harus memenuhi dua tuntutan harapan peran yang berbeda yang harus dilakukan pada saat bersamaan (Myers, 1983, Onsardi, 2002). Konflik peran dapat menyebabkan prustasi dan kebingungan pada individu yang bersangkutan (Wexley \& Yukl, 1977). Karena dalam keterbatasan waktu ia harus menentukan peran mana yang harus dipilih dan peran mana yang harus ditinggalkan. Menurut Miyers (1983) penelitian yang dilakukannya pada ibu rumah tangga bekerja, konflik peran merupakan bentuk dari interrole conflict (konflik antar peran) karena peran pekerjaan dan keluarga membutuhkan perhatian yang sama. Pada masa sekarang konflik antar peran merupakan konflik yang sering dialami oleh wanita. Konflik peran karena antara suami istri tidak pernah saling komunikasi membicarakan masalah-masalah dan kebutuhan-kebutuhan yang mereka inginkan, sehingga meraka sering tidak dapat melakukan penyesuaian atau menyelaraskan segala kebutuhan yang mereka inginkan (Sekaran, 1986).

Penelitian yang dilakukan oleh Stainess, et all (1986), Sekaran (1986) menyatakan bahwa para suami yang istrinya bekerja umumnya merasa kuatir bahwa 
kedudukan mereka sebagai pimpinan rumah tangga dan pencari nafkah bagi keluarga akan goyah. Selain itu kadang-kadang suami dapat mengalami kebingungan peran yang disebabkan oleh tuntutan masyarakat sekitar atau karena penyesuaian yang dilakukan terhadap istri tidak berhasil.

Konflik keluarga-pekerjaan terjadi karena muncul ketidaksesuaian antara hal yang ada dengan yang diharapkan. Konflik ini muncul sebagai akibat dari pekerjaan menggangu keluarga dan keluarga menggangu pekerjaan (Frone, Russell \& Cooper, 1992, Onsardi, 2002). Selain itu konflik keluarga pekerjaan merupakan suatu tingkat tertentu seseorang merasa tidak nyaman dengan tekanan-tekanan yang dialami di rumah (Kopelman, et all, 1983). Selain dengan adanya kondisi tersebut, maka ketidak nyamanan di rumah akan membawa pengaruh ke lingkungan kerja yang berdampak kepada kepuasan kerja.

Sumber-sumber munculnya konflik keluarga-pekerjaan terjadi ketika kehidupan seseorang berbenturan dengan tanggungjawabnya di kantor seperti masuk kerja tepat waktu, menyelesaikan tugas harian, serta kerja lembur (Frone, Russell \& Cooper, 1994). Melihat dampak dari ketiga faktor yang telah disebut dan diuraikan di atas, maka

diperlukan suatu upaya untuk menanggulanginya antara lain dengan menggunakan sumber-sumber positif yang ada disekitar individu yaitu dukungan sosial (social support). Parasuraman, Greenhaus \& Granrose, (1992) dan Onsardi (2002) mengartikan dukungan sosial sebagai tersedianya hubungan sosial, baik yang berasal dari atasan, teman seprofesi maupun keluarga maka kepuasan kerja seseorang akan tercapai..

\section{Kepuasan Kerja}

Kepuasan kerja (Job Satisfaction) adalah cara seseorang bekerja merasakan pekerjaannya yang merupakan generalisasi sikap terhadap pekerjaannya (Wexley et al, 1992). Kepuasan kerja merupakan hal yang bersifat individual. Setiap individu mempunyai tingkat kepuasan yang berbeda-beda, kepuasan kerja sebagai efektivitas atau respons emosional terhadap berbagai aspek pekerjaan. Menurut Asmawi, M,. (2017) kepuasan kerja adalah sikap menyenangkan atau tidak menyenangkan yang dirasakan 
karyawan yang muncul sebagai akibat dari pekerjaan yang dilakukan, dengan indikator: (1) Pekerjaan yang menyenangkan, (2) Ganjaran yang pantas, (3) Kondisi kerja, (4) Rekan kerja, dan (5) Kesesuaian kepribadian dengan pekerjaan. Faktor-faktor yang penting dalam mendorong kepuasan kerja adalah kerja yang secara mental menantang, ganjaran yang pantas, kondisi kerja yang mendukung, dan rekan-rekan kerja yang mendukung (Robbins, 2016). Kepuasan kerja juga didefinisikan sebagai serangkaian perasaan senang atau tidak senang dan emosi seseorang pekerja berkenaan dengan pekerjaannya sehingga merupakan penilaian karyawan terhadap perasaan menyenangkan, positif atau tidak terhadap pekerjaannya (Smith et al dalam Luthans, 1995). Kepuasan kerja menunjukkan pada sikap umum seseorang terhadap pekerjaan dan harapannya pada organisasi tempat ia bekerja. Kepuasan kerja menunjukkan pada sikap emosional positif yang berdasar dari pengalaman kerja seseorang. (Cocke, 1976 dalam Kamal 1999). Kepuasan kerja dikaitkan dengan perilaku kerja merupakan dua aspek yang saling mempengaruhi. Kebalikan dari kepuasan kerja yaitu frustasi dengan berbagai bentuk, fiksasi (terus menerus mengulang argumen), regresi (perilaku merajuk, marah atau prilaku yang tidak dewasa), withdrawl (menarik diri), agresi (sabotase, pengrusakan, gosip, mengeluh dan sebagainya) (Thoha, 2000).

Frustasi yang menyerupai ketidakpuasan kerja dapat mengarah pada perilaku agresif dengan penarikan diri, tindakan agresif berupa sabotase, memperlambat pekerjaan, sehingga melakukan kesalahan, mengeluh protes terus menerus, banyak terjadi pertengkaran dan permusuhan antar pekerja. Bila tindakan agresif dimasuki jalannya pekerjaan, akan merusak kualitas layanan, tak mau bekerja sama, dan akan menunjukan biaya yang mahal bagi organisasi (Tyson dan Jackson, 2000). Ketidakpuasan karena kompensasi yang tidak memadai atau pekerjaan yang menjemukan juga dapat mendukung insiden-insiden pencurian oleh pekerja. Mencuri uang, peralatan serta persediaan barang oleh pekerja merupakan masalah penting bagi organisasi. Kepuasan kerja sering ditentukan bersama-sama atas dasar karakteristik situasi kerja (kinerja organisasi) dan karakteristik pekerja, dijabarkan dalam teori 
Discrepancy yang mencakup determinan-determinan kepuasan kerja (Wexley et al, 1992).

Tiga jenis karakteristik pekerja yang mempengaruhi persepsi yang seharusnya adalah kebutuhan-kebutuhan (pengakuan dan penghargaan), nilai-nilai (keyakinan seseorang terhadap prilaku "yang benar dan yang salah"), dalam kepribadian (harga diri). Bila terdapat persepsi pekerja yang semakin baik terhadap kondisi-kondisi yang seharusnya ada dengan persepsi terhadap kondisi aktual, maka pekerjaan akan mndapatkan kepuasan kerja (Wexley, 1992).

Robins (1996) menjelaskan bahwa ketidakpuasan karyawan dapat dinyatakan dalam sejumlah cara, misalnya terus menerus mengeluh, tidak patuh, mencuri milik organisasi atau melecehkan sebagian dari tanggung jawab mereka. Terdapat empat respon yang berbeda satu sama lain yaitu :

1. Eksit : ketidakpuasan yang diungkapkan lewat perilaku yang diarahkan meninggalkan organisasi.

2. Suara : ketidakpuasan yang diungkapkan lewat usaha aktif dan kontsruktif untuk memperbaiki kondisi.

3. Kesetiaan : ketidakpuasan yang diungkapkan dengan secara pasif menunggu membaiknya kondisi.

4. Pengabaian : ketidakpuasan yang dinyatakan dengan membiarkan kondisi memburuk.

Dengan demikian pentingnya kepusan kerja yang tinggi karena :

1. Ada bukti yang jelas bahwa pekerja yang tak terpuaskan lebih sering melewatkan pekerjaan dan lebih besar kemungkinan mengundurkan diri.

2. Pekerjaan yang terpuaskan mempunyai manfaat kesehatan yang lebih baik dan usia yang lebih panjang.

3. Kepuasan kerja, pekerja dibawa pada kinerja perusahaan dan ke dalam kehidupan karyawan di luar pekerjaan (Robbins, 1996).

Pemikiran Trist (dalam Wexley, 1992) mengarah kepada sederet metodologi yang berbeda untuk mencoba dan memperbaiki moral, kepuasan kerja dan motivasi 
dengan cara; rotasi kerja, perluasan kerja, pengembangan kerja dan merancang ulang kerja (situasi kerja/kinerja organisasi dan pekerjanya/personal). Teori dua faktor memandang bahwa kepuasan kerja berasal dari sejumlah penyebab yang sangat berbeda dibandingkan ketidakpuasan kerja (Herzberg, Mausner \& Synderman, 1959, Herzberg, 1966 dalam Marini Purwanto \& M. Nasir, 2001). Teori ini menyatakan bahwa statisfier (pemuas) demensi kerja adalah pengakuan, otonomi dan tanggungjawab, dan pekerjaan itu sendiri dapat mempengaruhi kepuasan dan bukan ketidakpuasan, sedangkan pengaruh sebaliknya timbul karena dissatisfier seperti gaji, kondisi kerja, dan perilaku hubungan manusiawi atasan atau rekan kerja.

Studi Smith, dkk, 1969 dalam Marini Purwanto \& M. Nasir (2001) menyebutkan bahwa kepuasan kerja dipengaruhi oleh enam aspek: (1) menarik tidaknya jenis pekerjaan, (2) jumlah kompensasi yang diterima pekerja, (3) kesempatan promosi jabatan, (4) supervisi dari atasan, (5) dukungan rekan kerja, (6) kondisi temat kerja. Demensi pertama, menarik tidaknya jenis pekerjaan yang dilakukan oleh pekerja, menurut Luthan (1998) bahwa pekerjaan itu sendiri merupakan sumber kepuasan kerja dan sebagian dari unsur yang memuaskan pekerjaan adalah pekerjaan yang menarik dan menantang, pekerjaan yang tidak membosankan dan pekerjaan yang memberikan status. Kedua jumlah kompensasi yang diterima pekerja merupakan faktor multi demensi yang signifikan dan kompleks dalam kepuasan kerja (Judge, 1993 dalam Marini Purwanto \& M. Nasir, 2001). Upah yang diterima harus dapat memenuhi kebutuhan hidupnya seharihari dan tingkat upah yang diterima pekerja mencerminkan sejauhmana manajemen menghargai kontribusi seseorang dalam organisasi tempat mereka bekerja. Ketiga kesempatan untuk promosi jabatan juga penting dalam penilaian kepuasan kerja seseorang. Kebijakan promosi yang adil akan berdampak positif pada pekerja, mereka yang menerima kesempatan dipromosikan jabatan akan merasa senang, bahagia dan memperoleh kepuasan kerja atas dirinya, (Luthan, 1998). Keempat kemampuan atasan memberikan dukungan perilaku kepada bawahannya akan menumbuhkan kepuasan kerja bagi karyawan, karena mereka merasa mendapat perhatian dan dukungan yang cukup dari atasannya, (Marini Purwanto \& M. Nasir, 2001). Kelima dukungan rekan kerja akan 
menimbulkan kepuasan kerja bagi seorang karyawan, karena mereka merasa diterima dan dibantu dalam melancarkan penyelesaian tugasnya. Memiliki rekan kerja yang ramah dan mendukung dapat menimbulkan kepuasan kerja tersendiri bagi setiap karyawan secara individual, sedangkan kelompok kerja yang bagus akan membuat kerja lebih menyenagkan sehingga dapat menimbulkan kepuasan bagi setiap karyawan, (Marini Purwanto \& M. Nasir, 2001). Keenam kondisi tempat kerja merupakan faktor yang ikut mempengaruhi kepuasan kerja. Dalam kondisi kerja yang baik, bersih dan menarik akan memberikan kepuasan bagi setiap karyawan, (Marini Purwanto \& M. Nasir, 2001).

Penelitian yang dilakukan oleh Ostsroff (1992) menjelaskan bahwa kepuasan kerja dapat meningkatkan kinerja organisasi secara keseluruhan, namun tidak secara individu. Tetapi penelitian yang dilakukan oleh Iffaldino \& Muchinsky (1985) menyatakan tidak terdapat kaitan antara kepuasan kerja dan kinerja, karena masih banyak faktor lain yang terkait. Selain itu kepuasan kerja juga akan terkait dengan seberapa jauh mereka menganggap pekerjaan itu penting atau tidak. Sehingga mereka menganggap makin penting pekerjaan, makin sedikit ketidak hadiran (Scott \& Taylor, 1995 dalam Haliman, 1997).

Selanjutnya menurut Frone, Russel \& Cooper (1994) kepuasan kerja dapat dilihat melalui tiga demensi penting yaitu : (1) kepuasan pekerjaan merupakan respon emosional terhadap situasi kerja; (2) kepuasan pekerjaan seringkali ditentukan oleh seberapa baik hasil yang diperoleh atau diharapkan; dan (3) kepuasan pekerjaan mempresentasikan beberapa sikap terkait sebagai sumber kepuasan pekerjaan.

Selain sifat-sifat kerja di atas yang dapat mempengaruhi kepuasan pekerjaan masih ada faktor lain yang dapat mempengaruhi kepuasan kerja yaitu tekanan pekerjaan, keterlibatan pekerjaan, konflik keluraga-pekerjaan (Frone, Russell \& Cooper, 1994) dan dukungan sosial (Parasuraman, Greenhaus \& Granrose, 1992) Onsardi (2002). 


\section{Faktor-Faktor yang Mempengaruhi Kepuasan Kerja}

Hasil penelitian Frone, Russell \& Cooper (1994) menjelaskan bahwa faktorfaktor yang dapat mempengaruhi kepuasan kerja meliputi : tekanan pekerjaan, keterlibatan pekerjaan, konflik keluarga-pekerjaan, dan dukungan sosial (Parasuraman, Greenhaus \& Granrose, 1992).

\section{Tekanan Pekerjaan}

Tekanan pekerjaan merupakan suatu respon adaptif pada sutau situasi eksternal yang menghasilkan penyimpangan-penyimpangan fisik, psikologi dan perilaku bagi para partisipan organisasi (Luthan, 1995). Tekanan pekerjaan juga dapat merupakan suatu kondisi dinamik dimana seseorang individu merasa dikonfrontasikan dengan sebuah peluang, kendala dan tuntutan yang dikaitkan dengan apa yang sangat diinginkannya dan hasilnya dipersepsikan sebagai suatu yang tidak pasti dan penting (Schuler, 1980). Tekanan kerja dapat muncul dari interaksi individu dengan pekerjaannya yang dicirikan dengan perubahan-perubahan di dalam individu tersebut yang mendorongnya dari fungsi normal (Beerhr \& Newman dalam Luthan, 1995). Tekanan pekerjaan ini pula dapat berupa pekerjaan terlalu berat, tidak adanya peran yang jelas dalam pekerjaan, kurang otonomi dan bahkan wewenangnya sering dicampuri oleh atasannya (Frone, Russell \& Cooper, 1994).

Beban pekerjaan yang telalu berat ini dapat dilihat melalui pekerjaan yang dihadapi dan harus dikerjakan oleh pekerja sehari-hari, yaitu pekerja terlalu banyak pekerjaan yang dilakukan, merasa memiliki tanggungjawab kerja orang lain, merasa kerja teralu keras baik secara fisik maupun mental, merasa tertekan untuk mengikuti cara-cara baru dalam pekerjaan, mempunyai tanggungjawab yang penting sehingga bila keputusan yang diambil ternyata salah sehingga membuat kerugian yang besar bagi organisasi, pekerjaan yang membutuhkan waktu lama dalam penyelesainya (Frone, Russell \& Cooper, 1994, Yasin, 1999).

Tidak jelasnya peran dalam pekerjaan terlihat dari pekerja yang bingung dan kurang yakin mengenai apa yang harus dilakukan, kurang jelasnya tugas yang harus 
dilakukan, tidak terdapatnya kejelasan tujuan yang harus dicapai, dan pekerja merasa kurang yakin seberapa besar wewenang yang dimilikinya. Kurang otonomi atau wewenang ini terlihat dari sutuasi dimana pekerja tidak mempunyai kesempatan untuk mempengaruhi keputusan supervisor dan atau kurang dapat kebebesan untuk memutuskan diri dalam melakukan pekerjaan yang ada di unitnya, kurang dapat menggunakan inisiatif sendiri dalam melakukan sesuatu dan bahkan supervisor terlalu ketat dalam melakukan pengawasan (Frone, Russell \& Cooper, 1994, Yasin, 1999).

\section{Keterlibatan Pekerjaan}

Penelitian yang dilakukan oleh Lodahl dan Kejner dalam Djawa Alfons (1993) menjelaskan dua konsep keterlibatan pekerjaan. Pertama, keterlibatan pekerjaan merupakan tingkat indentifikasi psikologik individu terhadap pekerjaannya, atau pentingnya pekerjaan dalam gambaran dirinya secara keseluruhan, seperti melakukan pekerjaan dengan baik membuatnya bahagia dan bekerja seenaknya menimbulkan rasa bersalah dalm dirinya. Kedua, keterlibatan pekerjaan menunjukan kinerja individu yang terlibat dalam pekerjaannya secara psikologik dapat dilihat dari kinerjanya atau dengan kata lain pekerjaan bagi individu merupakan tempat mengekspresikan self image.

Keterlibatan pekerjaan mengukur derajat sejauhmana seseorang memihak secara psikologis pada pekerjaanya dan menganggap tingkat kinerjanya penting bagi harga diri (Blau \& Boal, 1987). Karyawan yang memperoleh kesempatan keterlibatan yang tinggi dalam pekerjaannya akan sangat memihak pada jenis kerja yang dilakukan dan benarbenar peduli dengan jenis pekerjaan itu. Bahkan karyawan yang mempunyai keterlibatan yang tinggi dalam pekerjaan diketahui mempunyai absensi kerja yang rendah (Luthans, 1995; Robbin, 1996). Keterlibatan pekerjaan ini dapat diketahui dari persepsi karyawan bahwa dirinya merasa mengalami peristiwa penting ketika dilibatkan dalam pekerjaan sehingga membuat sebagian perhatiannya berpusat pada pekerjaan dan merasa bahwa pekerjaan adalah merupakan bagian yang sangat penting dalam hidupnya (Frone, Russell \& Cooper, 1994). 


\section{Konflik Keluarga-Pekerjaan}

Konflik keluarga-pekerjaan timbul diakibatkan konflik peran yang terjadi pada karyawan, disuatu sisi harus melakukan pekerjaan di kontor dan disi lain harus memperhatikan keluarga secara utuh. Sehingga sulit membedakan antara pekerjaan menggangu keluarga dan keluarga mengganggu pekerjaan. Pekerjaan mengganggu keluarga, artinya sebagian besar waktu dan perhatian dicurahkan untuk melakukan pekerjaan, sehingga kurang mempunyai waktu untuk keluarga. Sebaliknya keluarga menggangu pekerjaan berarti sebagian besar waktu dan perhatiannya digunakan untuk menyelesaikan urusan keluarga sehingga mengganggu kegiatan pekerjaan (Frone, Russell \& Cooper, 1992). Konflik keluarga-pekerjaan ini terjadi ketika kehidupan rumah seseorang berbenturan dengan tanggungjawabnya di tempat kerja, seperti masuk kerja tepat waktu, menyelesaikan tugas harian, atau kerja lembur. Demikian juga tuntutan kehidupan rumah yang menghalangi seseorang untuk meluangkan waktu untuk pekerjaanya atau kegiatan yang berkenaan dengan kariernya (Frone, Russell \& Cooper, 1994).

\section{Dukungan Sosial}

Dalam kehidupan sehari-hari manusia membutuhkan orang lain untuk dapat memenuhi kebutuhannya. Di lingkungan pekerjaan, hubungan antara karyawan itu dibutuhkan untuk menyelesaikan tugas-tugas (Rini, 2001). Behnis, dkk dalam Erni (1995) mengemukakan dua alasan penting keberadaan dukungan sosial. Pertama, individu membutuhkan bantuan orang lain bilamana tujuan atau aktivitas pekerjaan demikian luas dan kompleks sehingga tidak dapat menyelesaikan sendiri. Kedua, hubungan antara karyawan itu mempunyai nilai sebagai tujuan yaitu pekerjaan yang menuntut hubungan saling membantu.

House dalam Etzion (1984) menyatakan bahwa dukungan sosial sebagai suatu transaksi interpersonal yang melibatkan perhatian emosional, bantuan instrumental, informasi dan penilaian. Bantuan yang diperoleh dalam hubungan interpersonl dibutuhkan dalam menunjang kelancaran organisasi. House dalam Cohen \& Syme (1985) menyatakan bahwa dukungan sosial adalah tindakan yang bersifat menolong 
atau membantu dengan melibatkan aspek perhatian, emosi, informasi, bantuan instrumen, dan penilaian yang positif.

Dukungan sosial mempunyai demensi penting dalam suatu hubungan interpersonal. Dukungan sosial dapat mengatasi problem psikologik. Penelitian yang dilakukan oleh La Rocco, et all dalam Watson \& De Bertali Tregerthan (1984) menyimpulkan bahwa dukungan sosial dapat mengurangi kecemasan, ganguan umum, dan simptom-simptom ganguan pada tubuh bagi orang yang mengalami stress pada pekerjaan. Sejalan dengan pendapat tersebut Strauss \& Salyes (1980) menyatakan bahwa dukungan sosial dapat mengurangi perasaan tertekan dan ketidakpuasan pada saat pekerja dihadapkan pada tekanan, kekakuan dari pekerjaan mereka. Parasuraman, Greenhaus \& Granrose, (1992) memberi demensi dukungan sosial sebagai tersedianya hubungan sosial, baik yang berasal dari atasan, teman seprofesi maupun keluarga. Lebih lanjut penelitian yang dilakukan oleh Parasuraman, Greenhaus \& Granrose (1992) menyatakan bahwa dukungan sosial dapat meningkatkan kepuasan kerja.

\section{Pengaruh Tekanan Pekerjaan, Keterlibatan Pekerjaan, Konflik Keluarga- Pekerjaan dan Dukungan Sosial terhadap Kepuasan Kerja}

\subsection{Pengaruh Tekanan Pekerjaan terhadap Kepuasan Kerja}

Karyawan yang mengalami tekanan terhadap pekerjan yang ia lakukan seharihari seperti beban pekerjan yang telalu berat, tidak adanya peran yang jelas sehingga membuat karyawan bingung apa yang harus dia lakukan dan tidak adanya kejelasan tujuan yang harus dicapai, kurangnya otonomi dan wewenang yang sering dicampuri oleh atasannya terlihat pada kondisi karyawan tidak mempunyai kesempatan untuk mempengaruhi supervisor, kurang mendapatkan kebebasan untuk memutuskan sendiri dalam melakukan pekerjaan yang ada (Frone, Russell \& Cooper, 1994; Yasin 1999; Rini, 2001 ). Tekanan pekerjaan menjadi perhatian yang makin meningkat karena mempunyai implikasi ekonomi yang signifikan untuk organisasi melalui ketidakpuasan karyawan (Jagdish. K. Dua, 1994). 
Tekanan pekerjaan dapat juga terjadi karena adanya ketidakseimbangan antara tuntutan pekerjaan dengan kemampuan seseorang untuk memenuhi kebutuhan yaitu antara lain pengembangan karier, upah yang diterima, dan kenyamanan fisik dengan tingkat pemenuhan kebutuhan dan tujuan yang disediakan lingkungan kerja (Rini, 2001). Penelitian Greenhaus \& Beutell (1995) menjelaskan bahwa tekanan pekerjaan berpengaruh negatif terhadap kepuasan kerja, hal ini disebebkan oleh pemahaman karyawan terhadap domain kerja adalah relatif kecil dalam memecahkan berbagai permasalahan yang ada di organisasinya. Hasil penelitian Jagdish. K. Dua (1994) menjelaskan bahwa tekanan pekerjaan mempunyai korelasi tinggi dan signifikan terhadap kepuasan kerja.

Hasil penelitian di atas didukung penelitian yang dilakukan oleh Bedein, et all, 1988; Frone, et all, 1992; Higgins, et al, 1992; Howard, et all, 1992; Kopelman, et all, 1983; O’Driscoll, et all, 1992; Frone, et all, 1994 yang mengatakan bahwa tekanan pekerjaan mempunyai pengaruh yang negatif terhadap kepuasan pekerjaan.

\subsection{Pengaruh Keterlibatan Pekerjaan terhadap Kepuasan Kerja}

Keterlibatan pekerjaan ini dapat diketahui dari persepsi karyawan bahwa dirinya merasa mengalami peristiwa penting ketika dilibatkan dalam pekerjaan sehingga membuat sebagian perhatiannya berpusat pada pekerjaan dan merasa bahwa pekerjaan adalah merupakan bagian yang sangat penting dalam hidupnya (Frone, Russell \& Cooper, 1994). Lebih lanjut dijelaskan bahwa dalam mendeskripsikan kondisi individu secara psikologi pada pekerjaannya dan menganggap tingkat kinerjanya yang dipersepsikan penting untuk harga diri atau sejauhmana seseorang memusatkan perhatinnya pada pekerjaan (Frone, Russell \& Cooper, 1994).

Penelitian yang dilakukan oleh Robinowitzs dan Hall (1977) mengatakan bahwa variabel hasil kerja yang paling kuat hubungannya dengan keterlibatan pekerjaan adalah kepuasan kerja. Hasil Penelitian Hoff, T. J, (1998) menjelaskan bahwa keterlibatan yang besar dalam manajemen dapat meningkatkan kesuksesan kerja. Penelitian memngenai hubungan kedua variabel ini pada umumnya menunjukan adanya hubungan 
yang positif. Hasil penelitian ini didukung oleh Frone, Russell \& cooper, 1994) yang mengatakan bahwa keterlibatan pekerjaan mempunyai hubungan positif terhadap kepuasan kerja. Menurut Rice, Near \& Hunt (1980) bahwa keterlibatan pekerjaan dapat mempengaruhi secara positif terhadap kepuasan kerja. Pendapat ini didukung hasil penelitian yang dilakukan oleh Frone, Russell \& Cooper ,1994; Yasin, 1999; Rini, 2001.

\subsection{Pengaruh Konflik Keluarga-Pekerjaan terhadap Kepuasan Kerja}

Konflik keluarga-pekerjaan merupakan suatu tingkat tertentu dimana seseorang merasa tidak nyaman dengan tekanan-tekanan yang dialami di rumah sehingga dapat membuat seseorang merasa tidak nyaman dengan tekanan-tekanan yang dialami di tempat kerja begitu pula sebaliknya (Kopelman, et all, 1983). Untuk menjelaskan pengaruh konflik keluarga-pekerjaan terhadap kepuasan kerja dan konflik pekerjaankeluraga terhadap kepuasan keluarga dapat digunakan teori aliran (Spillover theory). Menurut teori aliran apabila terjadi fit antara organisasi dan karyawan maka hal tersebut akan menularkan fit di rumah. Atau dengan kata lain apabila seseorang merasa bahagia di tempat kerja, kebahagiaan tersebut akan ditularkan pada lingkungan keluarga (rumah). Demikian pula sebaliknya, apabila seseorang merasa stress di tempat bekerja maka besar kemungkinan stress akan dibawa ke rumah (Lovelace \& Rosen, 1990).

Hasil penelitian Yang Nini, et all (2000) yang melakukan penelitian di Cina dan Amirika menjelaskan bahwa konflik keluarga pekerjaan dapat diakibatkan oleh kebutuhan keluarga. Sedangkan hasil penelitian Kinnunen Ulla dan Mauno Saija (1998) yang menjelaskan bahwa konflik keluarga pekerjaan berpengaruh negatif kepada kepuasan pekerjaan. Kopelman, et all (1983) mengemukakan adanya pengaruh yang negatif konflik keluarga-pekerjaan terhadap kepuasan kerja. Hasil penelitian ini didukung oleh hasil penelitian yang dilakukan oleh Staines \& O’Conner, 1980; Parasuraman, et all, 1992; Frone, Russell \& Cooper, 1994; Yasin, 1999; Rini, 2001, yang menjelaskan bahwa ada pengaruh negatif konflik keluarga-pekerjaan terhadap kepuasan kerja. 


\subsection{Pengaruh Dukungan Sosial terhadap Kepuasan Kerja}

Para peneliti menyatakan bahwa dukungan sosial menjadi bagian yang penting dalam upaya menanggulangi stress dalam domain kehidupan yang beragam (Beehr, 1985, Gore, 1987, Greenhaus dan Parasuraman, 1986, House, 1981, Kessler, et all, 1985 dalam Parasuraman, Greenhaus \& Granrose, 1992). Penelitian yang dilakukan oleh Rudd \& McKenry (1986) menjelaskan bahwa dukungan sosial berpengaruh positif terhadap kepuasan kerja. Hasil penelitian ini juga didukung oleh hasil penelitian Parasuraman, Greenhaus \& Granrose (1992) yang menjelaskan bahwa dukungan sosial dapat berpengaruh positif terhadap kepuasan kerja. Hasil penelitian Rini (2001) menjelaskan bahwa dukungan sosial berpengaruh positif terhadap kepuasan kerja, dimana dukungan sosial baik yang berasal dari atasan, teman seprofesi maupun keluarga sangat dibutuhkan untuk tecapainya kepuasan kerja.

\section{BAB III \\ FAKTOR-FAKTOR YANG BERHUBUNGAN DENGAN TURN OVER}

\section{Latar Belakang}

Secara umum, dunia kerja diluar rumah lebih banyak didominasi oleh pria. Kekuatan organisasi yang mereka bangun dalam dunia kerja mereka, otomatis akan di pengaruhi oleh karakter maskulin . beberapa penelitian mengatakan bahwa karakter maskulin lebih dominan dalam suatu lingkungan organisasi (Maupin dan Lehman 1994;Hull dan Umansky 1997;Hooks dan Cheramy 1989), dimana karakter maskulin adalah seperti yang diungkapkan oleh Dalton (1997), yaitu lingkungan kerja yang kompetisinya tinggi, tekanan kerja yang berat, pengendalian dan pengawasan yang ketat. Konsekuensinya, seseorang baik Pria maupun Wanita yang berkerja dalam suatu 
organisasi atau instansi pemerintahan harus dapat menyesuaikan dengan karakter maskulin dan mengurangi atau menghilangkan karakter feminimnya (Maupin dan Lehman, 1994). Menurut Kanter (1977) seperti yang di kutip oleh Maupin dan Lehman (1994) "Organizations clearly reproduce themselves. People in power (who are mostly masculine men) mentor, encourge, and advance people who are most like themselves ...".

Meningkatnya keterlibatan wanita dalam suatu organisasi yang dikatakan berkarakter maskulin menunjukkan bahwa wanita juga dapat menyesuaikan dengan karakter maskulin. Sebagai contoh, penelitian yang dilakukan oleh Maupin dan Lehman (1994) menunjukkan bahwa semua wanita pada tingkat partner memiliki karakter maskulin yang tinggi, dengan perincian $40 \%$ maskulin (Maskulin tinggi-Feminim lemah) dan $54 \%$ andrologini. Karakter andrologini maksudnya adalah seseorang yang memiliki karakter Maskulin dan Feminim tinggi sekaligus.

Menurut penelitian yang lain mengatakan bahwa kaum pria lebih memungkinkan dapat mendistribusikan hasil yang mereka peroleh di tempat mereka bekerja di bandingkan kaum wanita, ini di peroleh dari perbedaan potensial 12,979 pekerja dalam 30 sistem organisasi yang ada sehingga di peroleh korelasi antara kepuasaan kerja dengan jumlah gaji yang di terima, (Khan 1972). Dari hasil penelitian tersebut dapat disimpulkan bahwa semakin tinggi kesuksesan seseorang (baik Pria maupun Wanita), maka akan semakin tinggi nilai - nilai maskulin yang melekat dalam dirinya. Kalaupun level patner seseorang memiliki karakter Feminim yang tinggi. Tetapi akan selalu di barengi dengan karakter maskulin yang tinggi. artinya dalam diri individu tersebut telah melekat sifat andrologini (Maskulin Tinggi - Feminim Tinggi).

Maskulin ataupun feminim yang selanjutnya di sebut dengan Peran jenis (Sex Role) pada mulanya muncul dari pembagian peran yang di dasarkan pada jenis kelamin (sex) oleh masyarakat . maskulin ataupun feminim juga di katakan sebagai streotip. pengertiaan streotip itu sendiri adalah pelekatan sikap terhadap individu atau kelompok tertentu. streotip yang dimaksud dalam kaitan dengan penelitian ini adalah pelekatan sifat maskulin pada pria dan feminim pada wanita oleh masyarakat pada umumnya. 
Adanya streotip bahwa pria memiliki karakter karakter maskulin dan wanita memiliki karakter feminim telah menjadi salah satu dasar pemikiran penelitian bahwa terdapat perbedaan antara pria dan wanita dalam beberapa aspek seperti kepuasan gaji, kepuasan kerja, kemajuan karier dan aspek - aspek lain yang berkaitan dengan lainnya dalam suatu organisasi yang berbeda (Deaux 1985). Penelitian yang dilakukan oleh Collin (1993) yang menemukan bahwa wanita memiliki tingkat keinginan keluar yang lebih tinggi dibandingkan kaum pria. Penelitian yang dilakukan oleh Grimwood dan Pipplestone (1993), menjelaskan bahwa komposisi pegawai wanita dilingkungan pekerjaan menunjukkan perkembangan. Pegawai wanita telah banyak menunjukkan keberhasilannya dalam mengkombinasikan antara karier dan keluarga (family) serta memasuki karier profesional pada lingkungan perusahaan yang di dominasi oleh kaum pria seperti profesional akuntan publik, hukum, industri, dan perdagangan.

Kepuasan gaji yang diterima didasarkan pada teori equity pada kehidupan sosial, akan dapat membandingkan referent dalam menilai rasio input terhadap outcome bagi tugas yang ada. Persepsi rasa ketidakadilan (inequity) akan terjadi jika rasio tersebut tidak sama. Untuk menuju pada keadilan (equity), out come dan input dapat dirubah secara objektif atau psikologi (Adam 1965). Dalam hal ini gaji di pandang sebagai bagian dari sistem pendukung yang di gunakan oleh organisasi untuk memotivasi karyawannya dengan memenuhi aturan dan peraturan. Menurut (Brockner dan Adsit's,1986 dalam Lum et.al 1998) menemukan implikasi yang penting dalam suatu organisasi, dimana kepuasan gaji dan kepuasan kerja (Job Satisfaction ) berpengaruh terhadap keinginan keluar.

Kepuasan kerja menurut (Judge dalam Yusti Pujisari 2001), mengatakan bahwa keinginan untuk mengakhiri tugas atau meninggalkan organisasi berhubungan dengan kepuasan kerja. Individu yang merasa terpuaskan dengan pekerjaannya cenderung untuk bertahan dalam organisasi. sedangkan individu yang merasa kurang terpuaskan dengan pekerjaannya akan memilih untuk keluar dari organisasi. kepuasaan kerja yang dirasakan dapat mempengaruhi pemikiran seseorang untuk keluar. evaluasi terhadap berbagai alternatif pekerjaan, pada akhirnya akan mewujudkan terjadinya turnover karena 
individu yang memilih keluar organisasi akan mengharapkan hasil yang lebih memuaskan ditempat lain. kepuasan kerja sebagai suatu perasaan senang atau emosi positif yang diperoleh dari pengalaman kerja, yang berkenaan dengan individu, bukan kelompok dan menyangkut masa lalu, bukan masa yang akan datang. Price (1981) menyatakan bahwa ketidakpuasan seseorang dengan pekerjaannya akan menimbulkan keinginan untuk keluar dari organisasi. Penilaian individu terhadap posisi sekarang dan merasakan tidak puas dapat memicu seseorang untuk mencari pekerjaan lain yang akhirnya mempunyai keinginan keluar pada suatu organisasi.

Pertumbuhan ekonomi akan meningkatkan derajat kesejahteraan masyarakat, meskipun tidak merata. golongan yang sejahtera akan semakin merubah gaya hidupnya dengan pola budaya., tingkat pendidikan masyarakat akan meningkat seiring dengan semakin pesatnya kemajuan teknologi informasi secara global. Begitu pula dengan jumlah dan jenis pelayanan kesehatan berkembang jumlah populasi yang meningkat, permintaan yang tinggi, transportasi dan komunikasi. Sehingga akan berakibat kebutuhan dan tuntutan pelayanan terhadap kesehatan meningkat yang membutuhkan pelayanan yang cepat dan nyaman.

Keadaan seperti itu, akan mempercepat perkembangan industri jasa (Service) kesehatan. Rumah Sakit sebagai institusi yang bergerak dalam bidang pelayanan jasa kesehatan tidak sekedar menampung orang sakit (Ika,1998), namun harus memperhatikan aspek pelayanan pemakaian jasa.

\section{Turn Over (Keinginan Keluar)}

Keinginan keluar yang dikemukakan March dan Simon (1958), Mobley (1997), Price (1977) pada Lum et al (1998), ketiganya memprediksikan hal yang sama terhadap keinginan seseorang untuk keluar organisasi, yaitu evaluasi mengenai posisi seseorang saat ini yang berkenaan dengan ketidakpuasaan dapat memicu keinginan seseorang untuk keluar dan mencari pekerjaan lain. Meskipun hubungan antara alternatif pekerjaan dan keinginan keluar belum banyak mendapat perhatian, akan tetapi kepuasan gaji (pay satisfaction) dapat memprediksikan keputusan keluar terhadap pekerjaan pada saat 
mereka merasa memungkinkan untuk meningkatkan gaji, melalui pergantian terhadap pekerjaannya atau berpindah ketempat lain (Motowildo, 1983). Lebih lanjut dikatakan bahwa gender, kepuasan gaji dan kepuasan kerja dapat mempengaruhi keinginan keluar seorang karyawan, dimana semakin tinggi gaji yang diterima maka akan berdampak pada tingginya kepuasan kerja yang pada akhirnya akan berpengaruh kepada rendahnya keinginan keluar dan sebaliknya, apabila gaji yang diterima oleh seorang karyawan tersebut kecil maka akan berdampak pada rendahnya kepuasaan kerja yang pada akhirnya akan menimbulkan tingginya keinginan keluar (Jennifer M. George \& Gareth R. Jones, 1996).

Keinginan keluar merupakan variabel yang paling berhubungan dan lebih banyak menjelaskan perilaku keluar (Mobley et al.,1997 dalam Harif Amali Rivai 2000). turnover lebih mengarah pada kenyataan akhir yang dihadapi oleh suatu organisasi pada periode tertentu, sedangkan keinginan berpindah mengacu kepada hasil evaluasi individu mengenai kelanjutan hubungannya dengan organisasi dan belum diwujudkan dalam tindakan pasti meninggalkan organisasi. Abelson (1987), menyatakan bahwa sebagian besar karyawan yang meninggalkan organisasi karena alasan sukarela dapat dikategorikan atas perpindahaan kerja sukarela yang dapat dihindarkan (avoidable valuntary turnover) dan perpindahan kerja yang tidak dapat dihindarkan (unviodable voluntary turnover). Avoidable valuntary turnover dapat disebabkan karena alasan berupa gaji, kondisi kerja, atasan atau ada organisasi lain yang dirasakan lebih baik, sedangkan perpindahan kerja sukarela yang tidak dapat dihindarkan dapat disebabkan karena perubahan jalur karier atau faktor keluarga.

\section{Perbedaan Gender}

Jenis kelamin adalah penggolongan yang didasarkan atas perbedaan biologis, dalam hal ini pria dan wanita. Ciri-ciri biologis yang dimiliki masing-masing jenis kelamin sudah merupakan kodrat dan tidak dapat dipertukarkan antara Pria dan Wanita (Fakih, 1996). Pengertian gender pertama kali dikatakan sebagai penggolongan gramatikal terhadap kata-kata benda dan kata-kata lain yang berkaitan dengannya, yang 
secara garis berhubungan dengan dua jenis kelamin serta ketiadaan jenis kelamin atau kenetralan (Fakih, 1999).

Menurut Bowo (1996) dalam Lucia Diah (2001) Pandangan mengenai Gender juga dihubungkan dengan Maskulinitas dan Feminitas. Sifat Maskulin diidentifikasi sebagai sifat-sifat laki-laki, yaitu sifat superioritas, keras serta sifat kuat yang cenderung mempunyai konotasi positif dalam dunia kerja. Sifat-sifat seorang pemimpin sering diidentifikasikan sebagai sifat maskulin. Hal ini bertolak belakang dengan sifat-sifat Feminim. Wanita seringkali dikatakan lebih sensitif, lebih emosional dan peopleoriented.

Peran jenis menurut Lamke (1982) dalam Nuryoto (1992) dan Yusti Pujisari (2001) adalah stereotip yang dimiliki oleh manusia, yaitu berupa sifat feminim dan sifat maskulin. Istilah gender muncul dari pembagian peran berdasarkan jenis kelamin secara kultural dan sosial. Dalam hal ini, masyarakatlah yang menentukan karakter ataupun watak apa saja yang dikategorikan maskulin atau feminim dan masyarakat pulalah yang melekatkan sifat maskulin pada pria dan sifat feminim pada wanita. Hal ini karena secara tradisional, seorang pria identik dengan pekerjaan diluar rumah yang penuh dengan kompetisi. Hal ini mendorong pria untuk menjadi ambigius, agresif, dominan yang oleh masyarakat disebut dengan sifat maskulin. Sebaliknya, wanita identik dengan pekerjaan rumah. Seperti mengurus anak yang selanjutnya menimbulkan sifat- sifat penuh kasih sayang, hangat, lembut yang oleh masyarakat diidentikkan dengan feminim.

Pada ilmu sosial istilah gender dikatakan sebagai perbedaan antara laki-laki dan perempuan tanpa konotasi-konotasi yang sepenuhnya bersifat biologis (McDonald et al., 1997 dalam Samekto 1999 dan Lucia Diah 2001). Oleh karena itu pemahaman gender dalam penelitian ini lebih mengacu pada perbedaan yang tampak antara pria dan wanita akibat dari pembentukan sosial masyarakat yang melekat walaupun tidak disebabkan oleh perbedaan-perbedaan biologis yang menyangkut jenis kelamin (Yeni, 1999 dalam Lucia Diah 2001).

Bila ciri-ciri biologis pada jenis kelamin tidak dapat dipertukarkan atau merupakan sudah kodrat, sebaliknya, sifat maskulin dan feminim dapat dipertukarkan 
antara pria dan wanita. Seorang pria dapat memiliki sifat feminim dan begitu juga sebaliknya kaum wanita dapat mempunyai sifat maskulin (Yusti Pujisari 2001).

Nelson dan Quick (1985) dalam penelitiannya memperoleh hasil yang mengindikasikan bahwa pegawai perempuan secara relatif memiliki psikologis yang baik dan mental distress (stress yang positif) dan pegawai laki-laki relatif memiliki distress secara fisik yang baik (Jick dan Mitz, 1985 dalam Abdurahim, 1998, dan Lucia Diah 2001). Adanya stereotip atau pelekatan sifat maskulin pada pria dan feminim pada wanita telah menjadi salah satu penyebab munculnya hambatan (glass Celling) bagi wanita untuk bekerja diluar rumah atau untuk mencapai posisi puncak dalam organisasi. Aspek glass celling telah menjadi fokus dalam banyak penelitian dalam suatu organisasional selama puluhan tahun. Maupin (1993) dalam Yusti Pujisari (2001) mengklasifikasikan dua hal untuk menjelaskan munculnya fenomena glass celling, yaitu:

\section{Person-centered explanations}

Menurut Person-centered explanations, sedikitnya wanita yang menempati posisi atas dalam organisasi disebabkan karena personalitas atau pola perilaku wanita yang tidak sesuai untuk mengambil peran kepemimpinan. Wanita dipandang tidak memiliki kemampuan untuk mendominasi, kemampuan untuk memecahkan masalah dan tidak berani mengambil resiko. Lebih lanjut dikatakan bahwa terdapat ketidaksesuaian antara pencapaian posisi manajerial dan sense of feminity. Akibatnya setiap individu tersebut harus menyesuaikan dengan karakter maskulin bila ingin mencapai posisi puncak atau seperti yang dikatakan oleh (Kanter, 1977; Maupin, 1993 dalam Yusti Pujisari, 2001) bahwa harus terdapat "social conformity” bila seseorang ingin mencapai posisi puncak dalam organisasi.

\section{Situation-centered explanations}

Alasan utama sedikitnya wanita yang menempati posisi puncak dalam organisasi disebabkan karena dominasi pria yang kemudian menimbulkan diskriminasi atau ketidakadilan struktural dan kebijakan. Kesempatan untuk kaum wanita dibatasi dan 
terdapat ketimpangan yang mencolok antara kekuasaan (power) wanita dan pria. Dominasi pria yang ditunjukkan dengan sistem patriarki telah terbentuk melalui proses yang panjang dan telah terjadi selama berabad-abad (Yusti Pujisari, 2001).

Selain itu, Hook (1993) dalam penelitiannya menyatakan bahwa diskriminasi secara langsung terhadap perempuan dalam rekriutmen dan kompensasi mungkin saja terjadi. Oleh karena itu perlu adanya tekanan yang mendorong supaya secara sadar untuk mengurangi bias yang dilakukan melalui perubahan cara pandang terhadap perilaku. Laki-laki diharapkan memiliki perilaku agresif dan otonom dibandingkan perempuan (Eagly, 1987; Hoffman dan Hurst, 1990 dalam Lucia Diah 2001). Ditempat kerja, pegawai laki-laki sering memiliki posisi penting dan bertindak secara lebih otoriter dan dominan, disisi lain wanita akan lebih tunduk dan patuh pada aturan dan kebijakan yang dikeluarkan oleh perusahaan (Eagly, 1987 dalam Lucia Diah, 2001).

\section{Kepuasan Gaji dan Teori Keadilan (Equity)}

Kepuasan individu terhadap gaji yang diterima didasarkan pada teori equity yang berkenaan dengan motivasi individu untuk bertindak dalam organisasi. Individu akan menilai rasio input terhadap outcome. Bagi tugas yang ada dan membandingkan dengan referent. Persepsi rasa ketidakadilan (inequity) akan terjadi jika rasio tersebut tidak sama. Untuk menuju pada keadilan (equity), outcome atau input dapat dirubah, secara objektif atau psikologis; dapat merubah referent pembanding ; individu bisa menarik diri dari situasi atau terjadi Keinginan keluar (Adam 1965 ; Wlaster \& Berscheid 1978 ; pada Harder 1992). Dalam hal ini gaji dipandang sebagai bagian dari sistem yang mendukung yang digunakan oleh suatu organisasi untuk memotivasi karyawan dengan memenuhi aturan dan peraturan yang ada. Bagi pekerja individu, gaji di pandang sebagai suatu outcome atau reward yang penting.

Menurut Heneman dan Schwab (1988), kepuasaan gaji merupakan konstruk kepuasaan yang multidimensi yang terdiri atas empat subdemensi : tingkat gaji, struktur / pengelolaan gaji, peningkatan gaji, dan tunjangan. Kepuasan atas tingkat gaji di definisikan sebagai persepsi kepuasan gaji atau upah langsung, sedangkan kepuasan 
atas peningkatan gaji berkenaan dengan persepsi kepuasan dalam perubahan tingkat gaji. kepuasan atas struktur atau pengadministrasian gaji di definisikan sebagai persepsi kepuasan dengan hirarki gaji internal dan metode yang di gunakan untuk mendistribusikan gaji. kepuasan atas tunjangan menekankan pada persepsi kepuasaan dengan pembayaran tidak langsung yang diterima karyawan.

\section{Kepuasan Kerja}

Kepuasan kerja didefinisikan sebagai serangkaian perasaan senang atau tidak senang dan emosi seseorang pekerja berkenaan dengan pekerjaannya sehingga merupakan penilaian karyawan terhadap perasaaan menyenangkan, positif atau tidak terhadap pekerjaannya (Smith at.al dalam Luthans, 1995). Kepuasan kerja (job statisfaction) menunjukkan pada sikap umum seseorang terhadap pekerjaan dan harapannya pada organisasi tempat ia bekerja. kepuasan kerja menunjukan pada sikap emosional positif yang berdasarkan dari pengalaman kerja seseorang. (Cocke, 1976 dalam Kamal 1999).

Biasanya apabila seseorang pegawai bergabung dalam satu organisasi, ia akan membawa seperangkat keinginan, kebutuhan, hasrat dan pengalaman masa lalu yang menyatu sehingga membentuk harapan kerja. seseorang akan merasa puas jika terdapat kesesuaian antara harapan yang timbul dengan imbalan yang disediakan oleh pekerjaan (Devis, 1985 dalam Kamal 1999). Dengan demikian kepuasan kerja merupakan seperangkat perasaan pegawai tentang menyenangkan atau tidaknya pekerjaan mereka. Atau dengan kata lain kepuasan kerja adalah sikap sesorang terhadap pekerjaannya. Namun sebaliknya jika seseorang tidak puas dengan pekerjaanya akan memiliki sikap negatif terhadap pekerjaannya. Scermerhorn, Hunt dan Osbern 1982 dalam Ma'mun Dewabrata 1995), mengemukakan bahwa kepuasan kerja adalah derajat positif-negatif yang dirasakan sesorang mengenai pekerjaannya.

Kepuasan kerja biasanya berhubungan dengan teori keadilan, psikologis dan motivasi. Kepuasan kerja dipengaruhi oleh besar-kecilnya penghargaan. Pelibatan kerja dan reward. Luthans (1995), menyatakan bahwa kepuasan kerja memiliki tiga 
dimensi. Pertama bahwa kepuasan tidak dapat di lihat, tetapi hanya dapat di duga. Kedua kepuasan kerja sering ditentukan oleh sejauh mana hasil kerja memenuhi atau melebihi harapan seseorang. Sebagai contoh; Jika anggota organisasi merasa bekerja lebih berat dari pada anggota lainnya dalam satu departemen tetapi mereka merasa memperoleh penghargaan lebih sedikit dari yang mereka harapkan, maka mereka mungkin akan bersikap negatif terhadap kerja atasan dan rekan kerjanya. Dilain pihak jika mereka merasa lingkungan kerja telah memberikan kepuasan kerja, maka mereka akan bersikap positif terhadap pekerjaan mereka dan atasan mereka. Ketiga, kepuasan kerja mencerminkan hubungan dengan berbagai sikap lainnya dari pada individual. Smith dkk. (1969 dalam Kamal, 1999), menyatakan bahwa terdapat lima dimensi kepuasan kerja yang mempengaruhi respon efektif seseorang terhadap pekerjaan, yaitu:

1). Pekerjaan itu sendiri, sejauh mana suatu pekerjaan menyediakan kesempatan seseorang untuk belajar memperoleh tanggung jawab dalam suatu tugas tertentu dan tantangan pekerjaan yang menarik.

2). Bayaran, jumlah upah yang diperoleh seseorang sebanding dengan usaha yang dilakukan dan sama dengan upah yang diterima oleh seseorang lain dalam posisi kerja yang sama.

3). Kesempatan untuk dipromosi, kesempatan seseorang untuk meraih atau dipromosikan ke jenjang lebih tinggi dalam organisasional.

4). Atasan, kemampuan atasan untuk memberikan bantuan teknis dan dukungan terhadap pekerjaan yang menjadi tanggung jawab para bawahan.

5). Rekan kerja, sejauh mana rekan kerja secara teknis cakap dan secara sosial mendukung tugas-tugas rekan kerja lainnya.

Kepuasan kerja adalah bagian dari kepuasan hidup, bila seseorang memiliki kepuasan dalam pekerjaannya maka ia akan menikmati kehidupannya. Dalam kaitan ini banyak faktor yang mempengaruhi terhadap ketercapaian seseorang untuk menikmati kepuasannya. (Weis, Dewis, Englend \&Lofquist 1967 dalam Ma'mun Dewabrata, 1995), merincikan faktor-faktor yang mempengaruhi terhadap kepuasan seseorang dalam pekerjaannya, dikatakan paling tidak ada dua puluh variabel yang berpengaruh 
terhadap kepuasan kerja yaitu: 1).Kemanfaatan, 2).Prestasi, 3).Otoritas, 4).Kreatifitas, 5).Aktifitas, 6).Kemandirian, 7).Nilai-nilai moral, 8).Tanggung jawab, 9).Status, 10).Keamanan, 11).Pelayanan sosial, 12). Keanekaragaman Tugas, Variabel-variabel tersebut dinamakan variabel internal. Selanjutnya 13).Promosi, 14).Kebijakan Perusahaan, 15).Kompensasi, 16).Pengakuan, 17).Hubungan sosial dengan atasan, 18).Kemampuan teknikal atasan. Variabel-variabel tersebut dinamakan variabel ekternal. Kemudian 19).Hubungan dengan rekan kerja, 20). Kondisi kerja, dinamakan variabel kepuasan secara umum. Selanjutnya menurut Frone, Russel \& Cooper (1994) kepuasan kerja dapat dilihat melalui tiga demensi penting yaitu : (1) kepuasan pekerjaan merupakan respon emosional terhadap situasi kerja; (2) kepuasan pekerjaan seringkali ditentukan oleh seberapa baik hasil yang diperoleh atau diharapkan; dan (3) kepuasan pekerjaan mempresentasikan beberapa sikap terkait sebagai sumber kepuasan pekerjaan.

Dari dimensi-dimensi yang dijelaskan diatas maka dimensi yang dipergunakan dalam penelitian ini adalah menggunakan dimensinya Frone, Russel \& Cooper (1994). penelitian ini dijadikan indikator pengukuran terhadap kepuasan kerja karyawan.

\section{Pengaruh Gender, Kepuasaan Gaji, Kepuasaan kerja terhadap Keinginan keluar}

\subsection{Pengaruh Gender terhadap Keinginan keluar}

Survey yang dilakukan oleh American Woman's Society Of Certified Public Accountants (AWSCPA) menunjukkan bahwa alasan seseorang terutama wanita meninggalkan suatu organisasi adalah untuk mendapatkan kesempatan promosi jabatan dan kondisi kerja yang lebih baik. Menurut Hunton, dkk. (1996) dalam yusti pujisari (2001), ketidakpuasan kerja menyebabkan wanita memiliki keinginan untuk berpindah yang lebih tinggi dibandingkan kaum pria. Disamping itu, penelitian yang dilakukan oleh Hunter dan Schmidt (1990) mengatakan bahwa ada korelasi antara gender, kepuasaan kerja Terhadap keinginan keluar. Dalam penelitian yang dilakukan oleh 
Collin (1993) menunjukkan bahwa wanita lebih sering melakukan keinginan keluar dibandingkan kaum pria.

\subsection{Pengaruh Kepuasan Gaji terhadap Keinginan Keluar}

Kepuasan gaji merupakan kelanjutan konsep equity theory (Adam 1965; pada Lum 1998), yang menekankan bahwa kepuasan gaji disebabkan oleh perasaan yang berhubungan dengan rasa keadilan atas gaji yang dibayarkan. Perasaan ini merupakan hasil dari proses yang terus menerus dan setelah membandingkan dengan outcome yang lain. Teori ini didasarkan bahwa seorang pekerja memformulasikan rasio outcome-nya (termasuk gaji) dengan input. Rasio ini kemudian dibandingkan dengan rasio outcome (input) dari beberapa sumber yang menjadi acuan. Jika gaji yang diterima pekerja kurang dari yang lainnya, akan menimbulkan adanya perasaan yang diperlakukan tidak adil atas pembayaran yang diberikan.

Lum et.al (1998), menawarkan suatu pendekatan yang sama yang menyarankan bahwa kepuasan dan ketidakpuasan adalah fungsi dari ketidakcocokan antara apa yang dirasakan akan diterima oleh seseorang dengan beberapa banyak bayaran yang diterima seseorang. Ketidakpuasan atas gaji yang mencukupi pada umumnya menimbulkan keinginan keluar dari suatu organisasi dimana ia bekerja (Lum et al,.1998). Selain itu orang - orang yang memiliki opini yang tinggi terhadap kinerja pekerjaannya cenderung kurang terpuaskan atas gaji yang diterimanya (Motowildo 1982).

Seiring dengan peningkatan peran dan kebutuhan individu dalam organisasi saat ini, bagaimanapun gaji telah memperoleh perhatian yang semakin meningkat. (Murray \& Smith, 1988 dalam Lum (1998), dalam penyelidikan terhadap karir, pekerjaan dan kepuasan staf perawat pada rumah sakit, menemukan hanya $10 \%$ dari perawat yang terpuaskan dengan gajinya dan $46 \%$ tidak terpuaskan.

\subsection{Pengaruh Kepuasan Kerja terhadap Keinginan keluar}

Pada level individual, kepuasan seseorang terhadap suatu pekerjaan paling sering diteliti menggunakan variabel psikologi dalam hubungan antara kepuasan terhadap Keinginan keluar (Mobley, 1979). Pengaruh kepuasan kerja terhadap keinginan keluar 
ditentukan oleh affective disposition individu dan semakin postif disposition individu akan semakin kuat hubungan antara kepuasan kerja terhadap Keinginan keluar.

Hullin et al (1985), mengakui bahwa alternatif pekerjaan dan kepuasan kerja dapat memiliki pengaruh yang substansial pada Keinginan keluar pekerja pada berbagai populasi. Ketidakpuasan kerja telah sering diidentifikasikan sebagai suatu alasan yang paling penting yang menyebabkan individu meninggalkan pekerjaannya, (Price \& Muller, 1981; pada William \& Hazer 1986 ), menyimpulkan secara empiris bahwa ketidakpuasan kerja memiliki suatu pengaruh langsung pada pembentukan keinginan keluar.

Kepuasan juga dihubungkan secara negatif dengan keluarnya (turnover) karyawan, tetapi korelasi itu lebih kuat daripada yang di temukan pada kemangkiran. Faktor lain misalnya, kondisi pasar tenaga kerja, pengharapan mengenai kesempatan kerja alternatif, dan panjangnya masa kerja dalam organisasi itu sebenarnya merupakan kendala yang penting dalam keputusan untuk meninggalkan pekerjaan sekarang (Harif Amali Riva'I, 2001).

Bukti menyatakan bahwa suatu moderator yang penting dari hubungan kepuasankeluarnya karyawan adalah tingkat kinerja. secara khusus, bila seseorang tidak puas dengan pekerjaan, lebih kecil kemungkinannya untuk keluar daripada mereka yang mempunyai watak positif terhadap hidup (Robbin,1998).

\section{DAFTAR PUSTAKA}

Anjani, R. (2019). Tata Kelola Adminitrasi Keuangan, Dan Pembangunan Desa Tepi Laut Kabupaten Bengkulu Utara. Jurnal Pengabdian Masyarakat Bumi Raflesia, $2(2)$.

Asmawi, M. (2017). The effect of compensation, empowerment, and job satisfaction on employee loyalty. International Journal of Scientific Research and Management, 5(12), 7590-7599. 
Arkat, F. (2020). The Effect Of Transformational Leadership Style And Work Spirit On Employee Performance At Raffles City Hotel Bengkulu Indonesia (No. gtw9z). Center for Open Science.

Arifin N., (1997). "Performing Organization, Sebuah Format Pengembangan Organisasi dalam Era Perubahan". Journal Siasat Bisnis, Tahun IV, Vol. 7.

Barlett Kenneth R (2001) "The Relationship Between Training and Organization Commitment : A Study in the Health Care Field". Human Resource Development Quarterly. Vol. 12. No 4. Winter.

Bedeian, A. G, Buke, B. G \& Moffett, R. G (1988), "Outcome of Work-Family Conflict Among Married Male and Famale Professionals". Journal of Management, 14: 475-491.

Blau, G.J, \& Boal, K. R. (1987), "Concetualizing How Job Involvement and Organizational Commitment Effect Turnover and Absenteeism". Academy of Management Review, April, hal 290.

Boles James S. Howard W. Gary dan Donofrio Heather Howard (2001) "An Investigation Into The Inter-Relationships of Work-Family Conflict, FamilyWork Conflict and Work Satisfaction”. Journal of Managerial Issues. Vol XIII No. 3. 376-390

Brody, G. H, \& Pillegrini, A.D. (1986), "Material Quality \& Mother Child \& Father Child Interaction With School Aged Children". Journal of Developmental Psychology, 22 (3): 291-296.

Brooke Jr. Paul P, Russell Daniel W. dan Price James L (1988) "Discriminant Validition of Measures of Job Satisfaction, Job Involment, and Organization Commitment”. Journal of Applied Psychology. Vol. 73. No. 2, 139-145.

Bures R dan Henderson D (1995) "The Effect of Social Support and Gender on Worker's Stress on Job Satisfaction : A Cross National Investigation of Duel Career Couples". Journal of Applied Bussines Research. Vol 12 No. 1.

Cohen, J, \& Syme, S.L, (1985). Social Support and Health. London: Academic Press, Inc.

Crammer D., (1996). "Job Statisfaction and Organizational Continuance Commitment". Journal of Organzational Bahavior, Vol. 17. 
Darmawan, (1993). Hubungan Antara Komunikasi Interpersonal dengan Keterlibatan Kerja pada Tenaga Perawat di RS Bethesda. Tesis (tidak diterbitkan) Yogyakarta: Fakultas Psikologi UGM.

Davis Keith dan Newstrom John W. (1996) Perilaku Dalam Organisasi. Erlangga: Jarkarta.

Djawa Alfons (1993), Persepsi Terhadap Konplik Peran Dalam Hubungannya Dengan Keterlibatan Kerja pada Karyawan PT Tiga Arfa Bandung. Thesis (Tidak diterbitkan) Yogyakarta, Fakultas Psikologi UGM.

Ducharme, L \& Martin, JK ( 2000) "Unrewarding Work, Social Support, and Job Satisfaction: A Test of the Buffering Hypothesis" Work and Occupations, Vol. 27 No. 2, May, 223-243.

Dunseath J, Beehr T. A \& King DW (1995) "Job Stess Social Support Effect Across Gender, Education and Occupational Groups in a Municipal Workforce. Implications for EAP's and Further Research". Review of Public Personnel Administration. Winter

Erni Hidayati, (1995). Hubungan Antara Dukungan Sosial dan Harga Diri dengan Stess Kerja Guru SD di Kecamatan Wirobrajan Yogyakarta. Tesis (Tidak diterbitkan) Yogyakarta, Fakultas Psikologi UGM.

Etzion, D, (1984). "Moderating Effect of Social Support on The Stress Burnout Relationship". Journal Of Applied Psychology, Vol. 69.

Fakih, Monsour, (1999) Jender dan Perubahan Organisasi. Yogyakarta : Pustaka Pelajar.

Farr James L. Mathieu John E (1991) "Further Evidence for the Discriminant Validity of Measure of Organizational Commitment, Job Involvement, and Job Satisfaction”. Journal of Applied Psychology. Vol 76. No. 1. 127-133.

Frone, M. R. Russell, M dan Cooper, M.L (1992), "Antecedents and Outcome of Work-Family Conflict: Testing a Model of the Work-Family Interface". Journal of Applied Psychology. 77: 65-78.

(1994), "Relationship Between Job and Family Satisfaction: Causal or Noncausal Covariation ?". Journal of Management, Vol. 20. No. 3, 565-579.

Ganzach Y., (1998). "Intelligence and Job Statisfaction". Academy of Management. Journal, Vol. 41 No. 5. 
Ganster, D.C, Fusilier, M.R \& Mayer, B.T, (1986). "Role of Social Support in The Experience of Stress at Work". Journal Of Applied Psychology, Vol. 71 No.3. 102-110.

Gujarati Damodar N (1995). Basic Econometrics. Third Edition. United States Military Academy, West Point.

Hadi Sutrisno (1982). Statistik Jilid III. Yayasan Penerbit Fakultas Psikologi UGM

Haliman, (1997) Pengaruh Pendidikan formal, Pengalaman, Locus of Control pada Hubungan Antara Partisipasi Anggaran Dengan Kinerja dan Kepuasan Kerja. Tesis (Tidak diterbitkan) Yogyakarta, Fakultas Ekonomni UGM.

Higgins, C.A, Duxubury, L. E \& Irving, R. H (1992), "Work-Family Conflict in The Duel-Career Family". Organizational Behavior and Human Decision Processes, 51: 51-57.

Howord, A. (1992), Work and Family Cross Roads Spanning The Career. San Fransisco: Jossey Bass.

Iffaldino, M.T \& Muchinsky, P.M (1985) "Job Satisfaction and Performance: A Meta Analysis”., Psychological Bulletin, Vo 97, 251-273.

Imam Ghozali, 2001. “ Aplikasi Analisis Multivariate dengan Program SPSS". Universitas Diponegoro, Semarang

Indriantoro Nur dan Supomo Bambang (1999). Metodologi Penelitian Bisnis. BPFE Yogyakarta.

Isnovijanti Tita (2002) Pengaruh Dukungan Sosial Terhadap Stress Kerja dan Kepuasan Kerja (Studi Kasus di Polres Pati Polda Jateng) Tesis (Tidak dipublikasikan). MM Undip. Semarang

Jamal Muhammad (1997) "Job Stess, Satisfaction, and Mental Health: An Empirical Examination of Self-Employed and Non-Self-Employed Canadians". Journal of Small Business Management. Oktober.

Jiang, James. J dan Klein Gery (2000) "Social Support and Carieer Anchor Impact on the Career Satisfaction of the Entry-Level Information System Profesional". Journal of Management Information System. Vol. 16. No. 3, pp 219-240.

Jones. W. Steffy Douglas (1991) Applying Psychology in Business, The Hand Book for Manager and Human Resources Profesional. Lexingtoon, Books, Canada. 
Kamal, (1999) Pengaruh Perselisihan dan Gaya Evaluasi Kinerja Anggaran Terhadap Kinerja : Tekanan Kerja, Kepuasan Kerja Sebagai Variabel Mediasi. Tesis (tidak dipublikasikan) Fakultas Ekonomi UGM. Yogyakarta.

Kanungo, R. N, (1982), "The Concept of Allianation and Involvement Revisited". Psychological Bulletin, Vo. 86. No. 1.: 119-138.

Katz, D \& Kahn, R.L, (1978). The Social Psychology of Organization. Second Edition. New York: John Willey \& Son, Inc

K. Dua Jagdish. (1994) "Job Stressors and Their Effect on Physical Health, Emotional Health and Job Satisfaction in a University". Journal of Educational Administration. Vol. 32 No. 1. 59-78

Kinnunen Ulla, Mauono Saija. (1998) "Antecedents and Outcomes of Work-Family Conflict Among Employed Women and Men in Finland". Human Relation Journal. Vol.51 No.2. 157-177

Kopelman, R, Greenhaus, J. Connoly, T, (1983), "A Model of Work, Family, and Interrole Conflict: A Construct Validation Study". Organizational Behavior and Human Peformance, No. 32, pp. 198-215.

Lovelace, K, \& Rosen, B, (1990), "Differences In Achieving Person-Organization Fit Among Diverse Group of Managers". Academy of Management Journal, Vol. 22. No. 5. pp. 703-722.

Luthans, F. (1995), Organizational Behavior. International Editions, McGraw Hill Book Co. Singapore.

Ma'mun, Bisma Dewa Brata, (1995).” Identifikasi Nilai-Nilai Budaya Kerja dan Pengaruhnya Terhadap Sikap Kerja" ( Kasus pada Direktorat Produksi PT. IPTN), Forum Komunikasi Penelitian Manejemen dan Bisnis.

Marini Purwanto \& M. Nasir, (2001). "Pengaruh Variabel Role Conflict, Role Abiguity, dan Job Insecurity Terhadap kepuasan Kerja Akuntan Pendidik". Jurnal Bisnis Strategi. Vol. 7 Juli Th. V.

Mitchell, T.R (1985). People in Organization. Singapore. Mc Graw-Hill, Inc.

Moh. Nazir (1988) Metode Penelitian. Jakarta Ghalia Indonesia.

Moore, L.L, (1986), Not As Far As You Think. Massachussetts: Lexington Books. 
Muhari, (1983), Suasana Rumah dan Prestasi Belajar Suatu Studi Tentang Pengaruh Suasana Rumah Terhadap Prestasi Belajar Para Pelajar Sekolah Menengah Utama Tingkat Pertama di Jawa Timur. Disertasi (tidak diterbitkan) Yogyakarta, Fakultas Psikologi UGM.

Muluk, Hamdi (1996) "Ketidakberdayaan dan Perilaku Ugal-ugalan Sopir Metromini”" Jurnal Psikologi Sosial. No. 5. Th. 4. Januari. Fak. Psikologi UI, Jakarta.

Myers, D.G, (1983). Social Psychology. Tokyo: Mc Graw-Hill, Book Company

Onsardi, O. (2019). Effect Of Empowerment On Employees Performance (No. v7g9t). Center for Open Science.

Onsardi, O. (2019). Implementasi Manajemen Kinerja Di Universitas Muhammadiyah Bengkulu (No. kzyfx). Center for Open Science.

Onsardi, O. (2018). Loyalitas Karyawan pada Universitas Swasta di Kota Bengkulu. COSTING: Journal of Economic, Bussines and Accounting, 2(1), 1-13.

Onsardi, O. (2019). Implementasi Empowerment Dalam Meningkatkan Kinerja Karyawan (No. bgwju). Center for Open Science.

Onsardi, O. (2002). Pengaruh Tekanan Pekerjaan, Keterlibatan Pekerjaan, Konflik Keluarga-Pekerjaan Dan Dukungan Sosial Terhadap Kepuasan Kerja Karyawan Perguruan Tinggi Swasta Di Propinsi Bengkulu (Doctoral dissertation, program Pascasarjana Universitas Diponegoro).

Onsardi, O. (2019). Implementasi Human Capital Management (Hcm) Pada Universitas Muhammadiyah Bengkulu (No. n7yue). Center for Open Science.

Ostsroff, C. (1992) “The Relationship Between Satisfaction, Attitudes and Performance: An Organizational Analysis". Journal of Applied Psychology, December, 963-974.

Parasuraman, Greenhaus \& Granrose, (1992), "Roles Stressor, Social Support, and WellBeing Among Two Career Couples". Journal of Organizational Behavior, Vol. 13. 339-353.

Putri, S. H. (2020). Pengaruh Disiplin Kerja Dan Lingkungan Kerja Terhadap Kinerja Karyawan (No. tfbve). Center for Open Science.

Robinowitzs, S \& Hall, D.T (1977). "Oganization Research and Job Invelovment". Psychological Bulletin, Vol 84. No2. 265-288. 
Rini Juni Astuti, (2001) Analisis Hubungan Timbal Balik dan Faktor-Faktor Yang Mempengaruhi Kepuasan Kerja dan Kepuasan Keluarga Pada Industri Kesehatan. Thesis (Tidak diterbitkan) Yogyakarta, Fakultas Ekonomni UGM.

Robbins, P. S. (1996), Organzational Behavior, Concepts, Controversies, Aplications, Alih Bahasa, Hadyana Pajaatmaka, PT. Bhuana Ilmu Populair, Jakarta.

Sekaran, U, (1986), Research Methods for Business: A Skill-Building Approach. Second Edition, John Wiley \& Son, Inc. Singapore.

Shaevitz, M.H, (1991), Wanita Super. Terjemah, Yogyakarta, Kanisius.

Soelistyorini, (1992), Hubungan Antara Family Relationship, Urutan Kelahiran, Jenis Kelamin dan Toleransi Terhadap Prustasi Para Remaja. Thesis (tidak diterbitkan) Yogyakarta: Fakultas Psikologi UGM.

Strauss, G \& Salyes, L. R, (1980). Personal : The Human Problem of Management. Forth Edition, Prentice Hall of India, New Delhi.

Thoha M. (2000), Perilaku Organisasi. Rajawali Pers, Jakarta.

Tyson dan Jackson. (2000). The Essence of Organizational Behavior Person Education. Asia, Pte, Ltd.

Wexley, K.N \& Yukl, G.A (1977). Organization and Personnel Psychology. Illnois, Richard D. Irwin Home Wood.

Wexley et al., (1992). Organizational Behavior. Person Psychology. PT. Renika Cipta Jakarta.

Yang Nini, C. Chen Chao, Choi Jaepil, Zou Yimin (2000) "Sources of Work-Family Conflict: A Sino-U.S. Comparison of The Effect of Work and Family Demand". Academy of Mangement Journal. Vol. 43. No.1. 113-123.

Yasin Aziz, (1999), Studi Tentang Pengaruh Timbal Balik Antara Kepuasan Pekerjaan dan Kepuasan Keluarga. Thesis (Tidak diterbitkan) Yogyakarta, Fakultas Ekonomni UGM.

Yoder, D, (1979). Personal Management \& Industrial Relationship. $6^{\text {th }}$ edition, New Delhi: Prentice Hall of India Private Limited.

Zeithaml et al., (1994). "The Behavioral Consequences of Service Quality". Journal of Marketing, Vol. 60, April. 